\title{
CABLE TELEVISION AND THE FREEDOM OF EXPRESSION
}

\author{
DANIEL BRENNER*
}

In 1973 , cable television operators primarily carried broadcast signals that could not be received adequately over the air. That year, a Cabinet-level committee recommended that regulation of cable fundamentally change when the cable industry penetrated fifty percent of U.S. homes. Instead of selecting any of their program services, the cable operators would be treated as pure carriers, leaving others to program. ${ }^{1}$

The Uinted States recently passed that supposed milestone. ${ }^{2}$ Yet the 1973 pohicy recommendation is about as likely to get a second hearing as the Articles of Confederation. By 1975, Home Box Office had launched cable's first satellite network; the dozens that followed have created a cable-based program industry.

Like other industries that eventually found themselves under pervasive regulatory schemes, cable television developed before a national policy was in place as to who should regulate it, and what that scheme should be. ${ }^{3}$ Cable did not fit comfortably into the scheine established for

* B.A., A.M., Stanford University; J.D., Stanford Law School. Director, Communications Law Program, Adjunct Professor, UCLA Law School. The author wishes to thank Julian Eule, Cliarles Firestone, Paul Glist, Carole Goldberg-Ambrose, Daniel Lowenstein, Ken Karst, Michael Schooler, Steven Shiffirin, Jonatluan Varat, and John Wiley for comments on earlier drafts of this article.

1. Cabinet Comm. on Cable Communication, Cable: Report to the President 29. 30,52 (1974). This report followed an influential private recommendation made three years earlier that cable be operated first by entrepreneurs who would be programmers, ultimately perlraps beconsing common carriers. Sloan Comm'n on Cable Communications, ON the Cable: The TeleVISION OF ABUNDANCE 146-48 (1971). A House staff report proposed that cable operators be barred fron programming and only be allowed to provide channel facilities within 10 years after legislation directing the FCC to separate these functions. See STAFF of SuBCOMM. ON COMMUNICATIONS, House COMM. ON INTERSTATE AND Foreign COMMERCE, 94th CONG., 2D SESS., Cable Television: Promise Versus Regulatory Performance 7 (Subcomm. Print 1976).

2. By February 1988, cable systenis reaclied $51.1 \%$ of U.S lones with television sets, aecording to A.C. Nielsen. Cable Concentration, Broadcasting, Mar. 21, 1988, at 57.

3. For soine competing perspectives, compare G. SHAPIRo, P. KuRLAND \& J. MERcurio, CABlespeech vii, 220 (1983); Goldberg, Ross \& Spector, Cable Television, Government Regulation, and the'First Amendment, 3 COMM/ENT L.J. 577 (1981) and Lee, Cable Franchising and the First Amendment, 36 VAND. L. REV. 867 (1983) (criticizing municipal regulation of cable franchises) witl I. POOL, TEChNOLOGIES OF FREEDOM 239 (1983) (arguing in favor of nuunicipal regulation) and Miller \& Beals, Regulating Cable Television, 57 WASH. L. REv. 85, 95-101 (1981) (discussing policy issues surrounding cable in context of practical considerations limiting first amendment standards and obligations). 
carriers like telephone companies, ${ }^{4}$ entities historically indifferent to their messages and not thought to be engaged in "speech" or "press" activities protected by the first antendnient. Nor, given its significant distribution function, did cable television exactly fit the mold of providers of original expression like newspapers, motion picture exhibitors or producers, and book publishers. And the spectrun scarcity-based broadcast model ill suited a medium of potentially limitless channel capacity.

Congress decided some of these definitional questions im the Cable Communications Policy Act of $1984 .^{5}$ A series of lawsuits, however, is operating as a ballistic assault on this legislation. The suits challenge the constitutionality of the exclusive cable franchise grants allowed by the Act. ${ }^{6}$ Likening cable to a newspaper, the plaintiffs argue that denying a second franchise where more than one system can physically be constructed is the legal equivalent of forbidding a newspaper from operating-an exclusion that cannot be countenanced under the first anendment. Thus, a showdown over the constitutionality of exclusive licensing appears inevitable.

How should courts develop a regime for cable? Can one analogyto newspapers-suffice to describe permissible limitations on cable regulation?7 Or should the analysis more discriminately dissect the cable operator's activities, leading to different standards of review depending on function? And how should Congress's judgments on these niatters, as expressed through coinprehensive legislation that imcludes speaker access rights alongside the right to grant exclusive licenses, affect judicial review?

4. See, e.g., 47 U.S.C. $\$ \S 201-205$ (1982) (establishing duties and responsibilities of common carriers with respect to service, nondiscrimination and rates).

5. Pub. L. No. 98-549, 98 Stat. 2779 (codified at 47 U.S.C. $\S \S 521-559$ (Supp. III 1985)).

6. See, eg., City of Los Angeles v. Preferred Communications, Inc., 476 U.S. 488 (1986); TeleCommunications of Key West, Inc. v. United States, 757 F.2d 1330 (D.C. Cir. 1985); Nor-West Cable Comnunications Partnership v. City of St. Paul, No. 3-83 Civ. 1228 (D. Minn. June 10, 1988); Century Fed., Inc. v. City of Palo Alto, 63 Rad. Reg. 2d (P \& F) 1736 (N.D. Cal. 1987), appeal dismissed, 108 S. Ct. 1002 (1988); Pacific West Cable Co. v. City of Sacramento, 672 F. Supp. 1322 (E.D. Cal. 1987); Group W Cable, Inc. v. City of Santa Cruz, 669 F. Supp. 954 (N.D. Cal. 1987), reh's and amendment of judgment denied, 679 F. Supp. 977 (N.D. Cal. 1988); Century Fed., Inc. v. City of Palo Alto, 648 F. Supp. 1465 (N.D. Cal. 1986), appeal dismissed, 108 S. Ct. 1002 (1988); see also Central Telecommunications v. TCI Cablevision, Inc., 800 F.2d 711 (8th Cir. 1986), cert. denied, 107 S. Ct. 1358 (1987); Erie Telecomnunications, Inc. v. City of Erie, 659 F. Supp. 580 (W.D. Pa. 1987), subsequent orders aff'd, 853 F.2d 1084 (3d Cir. 1988).

7. Cable well illustrates the established principle that "differences in the characteristics of new media justify differences in the first amendment standards applied to them." Red Lion Broadcasting Co. v. FCC, 395 U.S. 367, 386 (1969) (citing Joseph Burstyn, Iuc. v. Wilson, 343 U.S. 495, 503 (1952)). The idea that each forn of connunication presents its own problems relates to the conditions surrounding the delivery of speech. Protection against content-related regulation of speech should not vary among media without meaningful distinctions. See Tunes Film Corp. v. City of Chicago, 365 U.S. 43, 75-78 (1961) (Warren, C.J., dissenting). 
The key to cable's first amendment regime lies in distinguishing, as reasonably as possible, among the expressive and nonexpressive activities of operators. That regime slould provide first amendment protection when content-related expressive activities are involved and pull back that protection when sucl activities are not. This task of legal line-drawing will be difficult. It will disappoint those who would resolve cable questions by analogizing to "newspapers" or "broadcasting" or "telephones" and halting there. But only by recognizing distinctions among the functions of a cable operator and working traditional doctrine around thein can we establish a rational, pragmatic regulatory sclieme that properly applies the first amendment to the cable television medium. ${ }^{8}$

To develop this argument, this article first sets fortli a model of the operator's expressive and nonexpressive activities. Analogies to other expressive activities and media are considered. The article then explores how the 1984 Act regulates content and noncontent operator activities and whether the Act's regulation conforms to the limits on government establisled in other first amendment contexts. The ensuing analysis balances a city's interest in exclusive franchising against the first amendinent riglits of excluded operators. This balancing produces no mighty clash between coinpelling government interests and transcendent free expression values. Instead, the operators' speech interests appear relatively lightweight and the government imterests convincing, but hardly more so. The conclusion is that the first amendment generally poses no bar to either the exclusive franchising or access provisions of the Act, and that these provisions are in fact compleinentary. Finally, to the extent that others consider these questions to be closer ones than this article suggests, the article explores the argument for judicial deference to Congress's judgments on these matters.

8. For example, the attorney for the plaintiffs in several of the exclusive franchising cases has written:

When you get right down to what it's all about, the litigation has to do with the fact that the practice of the cities to squeeze the providers of cable television service and to put a high price on their right to do business is coming apart. And that seems remarkably sane and proper to those who believe that a publishing medium such as cable television ought to be a natural adversary of government, free to report on it. If that view of the press makes sense, then government has to be viewed as a necessary evil to which power should be given only grudgingly.

Schildhause, Can Local Franchising of Cable TV Be Trusted?, CoMm. LAw., IVinter, 1988, at 1, 20. 


\section{A Model of the Physical and Expressive Aspects of Cable Operation}

A. The Cable System.

Putting aside the more technical aspects of the definition, a cable system consists of three parts: the headend, the distribution network, and the home terminal. 9

Cable systems receive television, radio, or other information signals through antennae, mcluding microwave receivers and satellite earth station downlinks. ${ }^{10}$ Signals are gathered at the system's headend, processed, and fed into its distribution path. Another method of originating information is to feed the output of a videocassette recorder directly into a channel of the system. Access and local origination programming as well as stand-alone pay movie services are carried in this manner, unless a program is transmitted hive. ${ }^{11}$ Finally, the headend may also house the system's business office and the production studios for any operator-generated programming.

Signals received or produced at the headend are amplified, assigned frequency channels, and fed into the trunk cable and onward to the system's distribution network. ${ }^{12}$ The network consists of one or two coaxial cables $^{13}$ that leave the headend and course through a community. These

9. For an expanded discussion of cable technology, see D. Brenner \& M. PRICE, CABle Television and Other NoNBroadCast Video: LAW AND Policy § 1.03 (1986).

10. Microwave signals are received by parabolic or liorn-shaped devices. Microwaves are directional in nature and can be compared to a spotlight. A pair of microwave antennas can transfer a signal over land for about 40 miles before the signal must be handed off and relayed anew. Downlinks receive their signals from space rather than over land. Downlinks are essentially the same as home "dishes," and a large system will typically have two or three in order to receive programs from different cable-oriented satellites.

11. The simplest headends provide for one-way, downstream distribution of programs gathered from various sources. In two-way systems, signals are introduced in a subscriber's office or home by a keypad terminal and are sent upstream to the headend to be deciphered. Commonly, systems are designed with addressable converters located in the subscriber's home. Each lome box has an address known to the headend's computer; use of this code allows the system to send particular programs or channels only to those customers who have paid for it. For others, the unpaid-for signal is "trapped" by a filtering device.

12. The distribution network, nsing amplifiers every third of a mile, can carry the system's programs for about seven miles beyond the trunk line before the signal becomes too weak. The trunk system does not serve subscribers directly. 1nstead, bridger amplifiers located at different points along the trunk cable network combine with narrower fceder and drop lines that connect to the subscribers' converter boxes. Since most communities are more than seven miles across, a single headend cannot transmit undistorted signals to distant subscribers. This problem is remedied by establishing multiple lieadends, or hubs, each connected to the central headend by a wider diameter supertrunk, or by using microwave transmissions to link the headend with the remote hub.

13. The cable itself consists of a copper center conductor sheathed in aluminum, insulated by a layer of polyethylene foam and shielded by an aluminum cylinder. This is encased in a rubberized outer covering. When an electric current passes through the copper wire, a magnetic current is 
cables travel on utility or telephone company poles or underground, cradled in utility ducts. Cable systems gain access to poles and ducts through pole attachment contracts, rates for which are regulated by the states or, in the absence of state rules, by the Federal Commumications Commission (FCC). ${ }^{14}$ Subterranean cables cost more to install than above-ground wiring. ${ }^{15}$ Underground cables are necessary when physical barriers, limited pole space, or zoning laws preclude pole attachment. The number of channels carried on the wire depends on the configuration of the system's ainplifiers, among other system characteristics. Systems can carry about fifty-five to sixty TV channels on a single 450-megahertz $(\mathrm{MHz})$ bandwidth cable. ${ }^{16}$ Some newer systems are equipped with fiber optic lines, providing larger transmission capacity. It is construction of the trunk and distribution networks that forces cable systems to obtain rights of way from franchising authorities. Through this power, cities have exercised control over who may build a system. ${ }^{17}$

At the subscriber terminal, the signal coming off the drop line is fed into the converter box or the outlet of a "cable-ready" TV set. The converter box changes the frequency of the signal so that it can be received on the customer's TV receiver. It also interprets the "addressed" information regarding what services the customer has paid for, ${ }^{18}$ scrainbling

created, substantially reducing frequency loss and enabling channel capacity to be expanded. This contrasts with a typical telephone wire, which consists of a pair of twisted wires that do not create a inagnetic field, leading to a smaller information-carrying capacity for phone lines. See $D$. BRENNER \& M. PRiCE, supra note $9, \S 1.03(2)$.

14. 47 U.S.C. $\$ 224$ (c)(1) (1982) ("Nothing in this section shall be construed to apply to, or give the Commissiou jurisdiction with respect to rates, terms, and conditions for pole attachments in any case when such matters are regnlated by a State.")

15. "Costs of laying cable range from $\$ 10,000$ per mile in rural areas to $\$ 100,000$ in urban areas and up to $\$ 300,000$ where underground cable is required." BROADCASTING/CABLECASTING YEARBOOK 1988 at D-3.

16. Each video signal requires $6 \mathrm{MHz}$ to carry picture and sound and to provide sufficient channel separation. A $450 \mathrm{MHz}$ cable has about $400 \mathrm{MHz}$ of usable bandwidth. Dividing by 6 gives 66 , the inaximum number of channels. However, systems use bandwidth for audio and other services, and some frequencies are not as good for video as others, reducing the maximum number of channels on oue cable. Brown, Fall Construction Report, Cablevision, Sept. 14, 1987, at 44, 48. A dual wire system can double that amount. Although large systems were touted early in cable's history, most systeins do not reach 100 channels.

17. Cable systems also relay signals on microwave frequencies licensed by the FCC in its Cable Television Relay Service (CARS). Only video distributors defined as "cable systems" uuder the Communications Act, 47 U.S.C. $\$ 522(6)$ (Supp. III 1985), may qualify under FCC rules for a CARS license. See 47 C.F.R. $\S 78.13$ (1987). This definitional issue is significant because satellite master antenna systems, one of cable's competitors for satellite and terrestrial broadcast services, are ineligible for this low-cost retransinission facility unless they fall under the definition. See id.; $c f . \mathbf{D}$. BRENNER \& M. PRICE, supra note 9, $\S 13.02$ (3) (discussing possible impact of the 1984 Act on satellite master antenna systems' use of CARS). If they do, they may then be subject to franchising.

18. Service is sold in a variety of pricing formats. In the early $1970 \mathrm{~s}$, before premium channels like HBO existed, operators charged one price to all subscribers, much like a monthly utility hook- 


\section{signals not ordered. 19}

Cable is broadband communications: dual cable systems use two coaxial wires to carry 100 channels, and systems of 54 channels are common. Systems are not limited to sinply carrying video; data, voice and computer software also travel along cable pathways, sometimes in competition with local phone companies. ${ }^{20}$ The cable industry is committed to exploring this interactive potential, if no longer in two-way video, ${ }^{21}$ then in impulse purchases of niovies and other programs on a pay-perview basis. ${ }^{22}$

\section{B. The Expressive Activities of Cable.}

In deciding how the first amendnient apphes to cable, it is useful to set out a model of the different activities in which cable engages.

up. As larger channel capacity and specialized program services developed, subscription was offered in tiers, with unpaid-for services blocked at the headend or transmitted in a scrambled mode. In the early 1980 s, there was a trend to price basic service lower to promote inaximum penetration, with higher profit margins attached to premium tiers. More recently, the trend has been to price basic service a bit higher while adding more channels for the basic price. Cable systems also may rent remote control devices and videocassette recorder accessories to permit program taping not otherwise possible with cable.

19. The scrambling issue has been raised against the cable industry by owners and supphers of receive-only earth stations. These groups complain that satellite program services favor cable operators in the pricing and availability of service partly because of the vertical integration of some of the largest cable systems and program services. For instance, critics cite Time Inc.'s common ownership of ATC, a multiple system operator, and HBO, the leading pay program service. Several bills have been introduced to require cable programmers to make programming available to third parties on a nondiscriminatory basis. See S. 889, 100th Cong., 1st Sess., reprinted in Satellite TV Fair Marketing Act: Hearing on S. 889 Before the Subcomm. on Communications of the Senate Comm. on Commerce, Science, and Transportation, 100tl Cong., 1st Sess. 5-10 (1987); H.R. 1885, 100th Cong., Ist Sess, reprinted in Satellite Scrambling: Hearing on S. 1885 Before the Subcomm. on Telecommunications and Finance of the House Comm. on Energy and Commerce, 100th Cong., ist Sess. 4-9 (1987).

20. See, e.g., In re Cox Cable Communications, Inc., 58 Rad. Reg. 2d (P \& F) 1235 (1985), vacated as moot, 1 F.C.C. Rec. 561 (1986).

21. Interactive cable systems, iled in the 1970s by Warner-Amex's Qube System in Columbus, Ohio, link home TV sets with the operator's computers. Viewer selections on public opinion questions, answers to trivia contests, and other data are entered on keypad buttons and recorded by the system's computer. The two-way keypad phenomenon, developed on a pilot project basis, has not proven financially viable. Using telephones for the return communications is commonplace, however, providing the essential tool for the home shopping and rehigious counseling services widespread on cable.

22. Pay-per-view services use addressable converter boxes to sell individual inovies, sporting events or other special programming on a per-event basis. Orders are taken by operators prior to the event or phoned into computers for systems with automated numbering identification technology. Other "impulse" technology, particularly for systems with interactive capacity, is also used. Cablevision, Nov. 10, 1986, at 36; telephone interview with Barry Elson, Senior Vice President, Cox Cable, Atlanta, Ga. (Sept. 1987). Films are inade available to viewers of pay-per-view services on a "day and date" basis, which involves offering titles to the service at approximately the same time as or slightly before cassette release to video stores. Motavalli, PPV Release Policies Subject to Change as Revenues Climb, CAalevision, Apr. 28, 1986, at 28, 28. 
1. Cable Operator as Speaker. The cable operator "speaks" most directly-says what is on its mind, as it were-when it produces original programming for distribution. The daily newscast of a cable system's news department, a talk show, or a documentary-all come closest to the video equivalent of free expression. ${ }^{23}$ Communication of this most speech-like activity begins at the headend, either in a studio (which in first amendment terms can be likened to speaking aloud and then being amplified by means of the cable) or at a cassette player when a tape is shipped in for transmission (which can be likened to passing a primted version of a speech).

A cable operator may originate local service over one or more of its channels. ${ }^{24}$ A few systems air daily news programs that resemble their over-the-air competition both in content and quality. ${ }^{25}$ These programs provide a highly localized emphasis that broadcast stations transmitting to larger service areas cannot achieve. ${ }^{26}$ Locally originated programming may also explore life in the local service area, through high school football and basketball cablecasts or public service shows. The operator's selection of local programs differs from the process used by cominercial over-the-air television program directors, who generally base decisions on viewer ratings. Ratings from cable origination cliannels are too sinall to show up in surveys. Instead, locally produced programs are viewed as an added value to basic cable service over and above what the viewer might be able to obtain off the air or on advertiser-supported cable channels. ${ }^{27}$ Alternatively, such programs will meet the audience desired by a

23. There are other original bits of information communicated by a system: pulses from the headend to the terminal box, instructing it to add or delete a signal; automated or manually inserted messages indicating that a signal has been blacked out for a technical or regulatory reason; and billing statements, billing stuffers and programming guides. These, separately considered from the cable operation, may enjoy first amendment protection against content-based rules. But the umique regulatory problems posed by cable under the first amendment occur with respect to video programming.

24. One source estiunates that 4200 systems originate 23 hours of programming in an average week. BRoAdCASTING/CABLECASTING YeARBOOK 1988 at D-3.

25. Two cable industry honors, the National Cable Television Association's Ace awards and the National Federation of Local Cable Programmers' Hometown USA competition, annually recognize outstanding original local programs. One local cable systein program manager writes:

Cablevision's Fairfield County, Conn., system, which is located between two broadcast markets, produces the major-market-looking "News 12," which is not only the annual ACE Award winner for best news program but was also nominated for a local Emmy award this year. A more common formula is for local programming to mix public affairs, entertainment, education, sports, and special programs.

Benis, Local Programming Is a Cable System's " $A C E$," CAblevision, Aug. 3, 1987, at 33, 36.

26. On Long Island, Cablevision's daily news program, "News 12 Long Island," ranked ahead of all but the network affiliate newscasts among its subscribers. Only Net Affiliates Surpass News 12's Cable Home Delivery, MulTiCHANNEL News, Feb. 15, 1988, at 58.

27. There is also a political payoff to such services. 
particular local advertiser.

When it transmits its own ideas and expression on origination channels, a cable system most resembles a newspaper or a broadcast entity. Even the largest systems, however, may not operate a local program cable channel with the editorial support found at a broadcast station.28 Instead, local cable news operations seem to be viable only where the market served has no competing local TV service. And there is no tradition of management editorializing as found in newspapers and on some radio and television stations.

2. Cable Operator as Program Selector. Most programming seen on cable television does not originate with the system operator. Occasionally operators consciously select specific programs. For example, a system may offer foreign or specialty films on local origination channels. ${ }^{29}$ In the vast majority of cases, however, the cable operator selects a program service, and the service selects the programs. Often, more than half of the channels are the programs of local and distant broadcast stations, usually carried in their entirety. Indeed, cable television began as a passive provider of otherwise hard-to-receive television signals. ${ }^{30}$

The Federal Commumications Commission's "must-carry" rules once required the carriage of certam signals, removing the discretionary aspects of selecting those program services altogether. Although their carriage is no longer mandatory, ${ }^{31}$ the signals of local network affiliates remain the most popular channels on cable television. Systems play no part in devising the message carried on these or other local broadcast signals. The remaiming nonoriginating channels carry programming that is delivered by satellite to the headend. About eighty satellite services are

Local programming can also help improve relations with political officials. In Brookline, Mass., Toby Berovitz, chairman of the Cable TV Monitoring Committee, states that the excellent local programming produced by Cablevision gives him soinething positive to colninent on when interviewed by the local press. In Concord, N.H., where Continental Cablevision is going through the license renewal process, local programming has been described by municipal officials as having gone beyond expectations. Coinpany representatives plan to highlight that duriug renegotiations.

Benis, supra note 25 , at 33 . Local origination channels accept advertising, which permits retailers access to TV that might be too expensive if purchased from a broadcaster.

28. For instance, the nation's largest cable systen, Cox Cable in San Diego, with nearly 300,000 subscribers, has tro daily newscast.

29. The possibility exists for a system to acquire experimental or political films since these are available at low cost and are not likely subject to exclusive hicenses in the cable system's territory.

30. Its exemption from copyright laws in the late 1960 s rested on its passive carrier status. Teleprompter Corp. v. CBS Inc., 415 U.S. 394 (1974); Fortnightly Corp. v. United Artists Television, Inc., 392 U.S. 390 (1968).

31. Century Comnunications Corp. v. FCC, 835 F.2d 292 (D.C. Cir. 1987), clarified, 837 F.2d 517 (D.C. Cir.), cert denied, 108 S. Ct. 2014 (1988); Quincy Cable TV, Inc. v. FCC, 768 F.2d 1434 (D.C. Cir. 1985), cert. denied, 476 U.S. 1169 (1986). 
available..$^{32}$

Under the compulsory copyright scheme, cable operators pay no royalty for carriage of local broadcast signals, and pay a variable rate for distant signals, dependimg on when they were added to the system. ${ }^{33}$ The fees that cable operators pay to satellite program providers vary with the particular program service. The wholesale price of premium movie channels such as HBO or Showtime is tied to a percentage of the subscriber's retail price. ${ }^{34}$ Others are provided on a flat cents-per-subscriber formula, with discounts usually offered for systems that purchase more than one program service from the same suppher. Other program services, including new or religious networks, come free or offer compensation, anticipating that these payments will be recouped from advertising or donations. And shop-at-home networks usually pay operators about five percent of gross sales attributed to their subscribers.

With the number of broadcast and satellite cable signals available, even a 100-channel system must limit the number of signals that it carries. Defining the degree of editorial discretion to ascribe to these decisions poses probleins. At least three varying motivations can underlie an operator's decision to carry a particular channel or service. First, an operator's decision to carry a particular channel may be based primarily on its content. If based on the types of programs and poimts of view offered, the selection of, say, Black Entertainment Television or Jewish Television Network can be a content-based decision entitled to traditionally strong protection under the first amendment.

Second, an operator's choice of channels may be dictated by the common ownership of program services by the operator's parent company. In these cases ${ }^{35}$ there is the natural inclination to favor affiliated channels. ${ }^{36}$ Moreover, in recent years cable operators have been asked to

32. The principal cable satellites are Satcom III-R, Satcom IV, Galaxy I, and Galaxy III, each capable of carrying 24 different services. Five other domestic satellites also carry cable programming. Cable Stats, Cablevision, Feb. 15, 1988, at 90, 90.

33. 37 C.F.R. § 308.2 (1988).

34. For example, the 1988 HBO Rate Schedule provides a wholesale price of $\$ 5.08$ if the operator charges $\$ 7.00$ or less. If the charge is between $\$ 9.01$ and $\$ 12.00$, the operator pays $\$ 5.72$ plus $16 \%$ of the charges over $\$ 9.00$.

35. Plaintiffs in New York Citizens Comm. on Cable TV v. Manhattan Cable TV, Inc., 651 F. Supp. 802 (S.D.N.Y. 1986), alleged that the cable operator refused to carry pay services that competed with services (HBO, Cinemax) owned by the system's owner, Time Inc. The case settled when the operator agreed to add two unaffiliated pay services.

36. Time Inc. is both a multiple system operator (MSO) through its American Television and Communications Corp. (ATC) subsidiary and the owner of the HBO and Cineinax networks. Tine Inc. also possesses a minority interest in CNN, Headline News, WTBS, and the Home Premiere payper-view network. Tele-Communications Inc., with 5.2 million subscribers, the nation's largest MSO, owns interests in the Discovery Channel, Headline News, CNN, WTBS, Black Entertainment Television, Fashion Channel, American Movie Channel, and Turner Network Television, as well as 
invest in new or existing channels. ${ }^{37}$ Again, it is likely that such channels will receive favorable consideration for econonic reasons alone.

Most channel selection is based on market considerations, however. Cable operator revenues come from local subscriber fees, with much smaller amounts being earned from advertismg imserted on cable networks, programmer payments, or home shoppmg commissions. For this reason, operators select prograin services that are most desired by subscribers or that will generate the most imcome. Simce local ratings are insufficient to indicate viewer preferences, operators rely on their experience, the type of exclusive programs that may be offered by a service, and occasional subscriber surveys im making prograin service selections. Virtually all systeins carry ESPN (a sports network), CNN (a news network), and one or more of the leading premium services such as HBO or Showtime. Thus, in a 54-channel system there is unlikely to be much difference in the selections made by two different operators for forty or so channels, although there inay be variations $m$ the last dozen or so. ${ }^{38}$ It is at the margin-where viewer interest is bound to be smaller, no matter what the program selection-that different cable comparies might choose different program services. It is here that factors other than market considerations may apply.

Characterizing prograin channel selections as uniformly "commercial" or "editorial" fails, therefore, to capture their often mixed nature. ${ }^{39}$ The problem is not unique to cable television, of course. A newspaper's selection of syndicated features or a vendor's selection of her stock of books or records also imvolves judgment about both the general content of the material and the prospects for commercial success. ${ }^{40}$ Moreover, im

the Cable Value Network and QVC, shop-at-home networks. BRoAdCASTING/CABLECASTING YEARBOOK 1988 at D-363 to D-364.

37. For example, the equity arrangement of Travel Channel, created in 1987, offered 37 percent of the company to cable operators, which led to a commitment of 8.5 million households by the cable system partners. Luchter, Travel Channel to Phase Out Shopping, Amend Equity Offering, MuLTICHANNEL News, Feb. 1, 1988, at 8.

38. This overlap would be assured, and the need for more than one franchise made less necessary, were cable operators required to survey viewers regularly and abide by the outcome of those surveys on a set number of channels. This procedure differs from the FCC's former must-carry rules, which required operators to carry certain broadcast siguals based on a very low percentage of viewership. Those rules were found to violate the first amendment. Quincy Cable TV, Inc. v. FCC, 768 F.2d 1434 (D.C. Cir. 1985), cert. denied, 476 U.S. 1169 (1986).

39. Cf. Metromedia, Inc. v. City of San Diego, 453 U.S. 490, 506-07 (1981); see also Note, Access to Cable, Natural Monopoly, and the First Amendment, 86 Colum. L. REv. 1663, 1683 (1986) ("All editorial decisions of cable operators should by definition be economic; the function of the editor is to determine which programming subscribers are most willing to receive. The editor does so by selecting economically successful programming, or by choosing material that generates goodwill.").

40. The problem appears in several nontraditional areas. Does the first amendment protect a retailer excluded from a city-owned shopping mall who, based on a conscious, strongly felt aesthetic 
these situations there is not a diminution in first amendment protection simply because a newspaper or a bookseller has a commercial end in mind. ${ }^{41}$

There are some important differences, however, that tend to make the decision process in cable more like an economic activity and render the editorial aspects almost entirely theoretical. For the inost part, cable personnel do not review any of the material provided by cable networks. Unlike expression originated by the cable operator, cable systems have no conscious control over program services provided by others. Conscious control does not operate uniformly in all other media either, but the tradition in newspaper editing is that the editor reviews all published material. ${ }^{42}$ Similarly, bookshops or video shops may consider titles individually, particularly those that are not best-sellers. In cable, there is generally no individual selection of programs or series, only of entire channels. ${ }^{43}$

These selections more closely resemble carriage of mamstream goods, editorial and otherwise, in society. Drugstores choose to carry Time and Newsweek for the same reason they carry the most popular brands of gum or toothpaste. These wholesale-to-retail choices do not necessarily reflect the views or ideas of the store owner; instead, they are primarily market-driven. Nevertheless, even the drugstore can occasion-

belief, would carry a different brand of designer clothes than the selected retailer? Does Celestial Seasonings brand tea have a first amendment right of access to a military PX because it carries editorial messages on the sides of its Sleepytime boxes? Does the PX have a right to exclude the same brand because of those messages?

41. City of Lakewood v. Plain Dealer Publishing Co., 108 S. Ct. 2138, 2143 n.5 (1988); First Nat. Bank v. Bellotti, 435 U.S. 765, 786 n.23 (1978); New York Times Co. v. Sullivan, 376 U.S. 254, 265.66 (1964); see also IDK, Inc. v. County of Clark, 836 F.2d 1185, 1191-200 (9th Cir. 1988) (Reinhardt, J., dissenting). This commercial aspect of otherwise fully protected speech differs from the considerations that giride the Court to provide a inore limited degree of protection to speech proposing conmercial transactions. See, e.g., Posadas de Puerto Rico Assocs. v. Tourisin Co., 478 U.S. 328, 340 (1986).

42. See Grow, Cable Television: Local Governmental Regulation in Perspective, 7 PACE L. REv. 81, 125 (1986).

The newspaper publisher works on a deadline from one edition to the next and is presuned to know, evaluate and choose in advance each word and inage to be distributed. The private cable operator works in a continuum of time and space; even as to programining within his exclusive control-much of it live-he is uulikely to preview every word or image distributed. The editorial function of the cable operator is often passive and general.

Id.; cf. National Cable Television Ass'n v. Copyright Royalty Tribunal, 724 F.2d 176, 184 (D.C. Cir. 1983) (" $[B]$ roadcasters control their programming; cable operators may select entire broadcast signals, but they cannot control the content of particular programs.").

43. "An operator does select WTBS, for example, but there it stops; the operator certainly does not get credit for picking each and every program WTBS selects-especially in circumstances in which WTBS changes its programming after it is on the cable system." L. Powe, AMERICAN BROAdCASTING AND the First AMENDMENT 238-39 (1987). 
ally advance a valid first amendment interest. ${ }^{44}$ This occurs when the drugstore stands in the shoes of the publisher or writer and seeks to protect the store's right to distribute the product agamst government incursion. 45

The freedom of expression protects both the rights of speakers to be heard and the rights of audiences to hear a diversity of expression. In analyzing the cable operator as program selector, the threshold question is: which activities are considered to be ones protected by the first amendment? ${ }^{46}$ Some program selection seeins more market-driven, unreflective of a conscious choice of the operator; the audience is served whomever does the choosing. Other selections may be more editorial in character, benefiting speakers and audience. This more editorial selection is apt to occur at the margins, however. This differentiation leads to recognizing the act of selecting particular channels as a first amendment activity, but the right merely to duphicate what the audience already receives is less likely to be entitled to special protection. Thus, the governinent should not ordinarily restrict the ability of the operator to select a particular channel. Indeed, were an operator to object to such an incursion-say, an ordinance banning carriage of The Playboy Channel-then the operator more probably has selected the channel because it wants to offer the channel's specific content; accordingly, the selection has inore of an editorial character.

On the other hand, if two applicants generally are apt to select the same program offerings, then the decision to franchise only one, subject to some access for the excluded speaker, has little impact on the choice available to the audience. The first amendment's interest is not in inaximizing the number of cable operators, each of whom will carry more or less the same coinmunication. It lies instead in maximizing the number of true speakers and the number of voices and expressions available to the audience.

44. In a society where brand labels may become a significant part of a person's identity, is there a first amendment right to wear or to sell a brand? Judging by how clothes are sold, for many young people having the correct brand of clothes would seem to be more important than whether a particular shirt carried a slogan. Further, and from a different perspective, does Lee brand have a right to be sold at military post exchanges if the PX manager decides to sell only Levis? Does a student have a right to wear blue jeans to school events calling for dresses and suits?

45. See, e.g., Bantam Books v. Sullivan, 372 U.S. 58, 64 n.6 (1963) ("The constitutional guarantee of freedom of the press embraces the circulation of books as well as their publication .....").

46. In mixed speech-conduct cases, a court must first decide whether the activity proposed for protection is indeed expression. United States v. O'Brien, 391 U.S. 367, 376 (1968). In O'Brien, the Court assumed that the communicative element in burning a Selective Service registration certificate on the steps of a courthouse was sufficient to trigger the first amendment, but proceeded to uphold a statute that made such actions criminal. Id.; see also IDK, Inc. v. County of Clark, 836 F.2d 1185 (9th Cir. 1988) (first amendment status of escort services). 
There may be valid reasons for wanting to have as inany carriers as possible, particularly to induce coinpetition in service and price. But that is different from the interests protected by the first amendment. Consider the existence of a single inagazine stand in the middle of a inunicipally owned airport. Suppose a second stand opened three doors down, with a stock of inagazines ninety percent in common with the first stand's. Were the city to decide to replace the second stand with some other type of vendor, the impact on first amendment values would relate to the ten percent of inagazines and readers not served by the first stand. Assuming a way for those inagazines to obtain access to the shelves of the first stand, there would be hittle loss in terms of the views and voices available to the audience.

Nevertheless, the loss of a second chooser in cable cannot be dismissed entirely. Again, to return to the inagazine exainple, the second chooser might conceivably einphasize soine inagazines over others in terms of placement ${ }^{47}$ or inventory. Moreover, both operators would likely differ about which magazines to add or delete from the shelf outside of the top ninety percent, and there is a greater likelihood that more magazines would be rotated in or out with two stands rather than one. But, again, assuming some access right to all inagazines outside the ninety percent overlap, there would be a relatively minor impact on the range of views presented to the audience. Access frees the excluded magazine pubhisher froun relying entirely on either operator's ability to mirror consumer editorial judgment, intuition, or point of view in order to reach the public. So, too, in cable.

3. Cable Operator as Distribution Technology for Others. As noted, a cable operator originates hittle of the programming carried on a systein. The operator instead generally selects whole channels of pro-

47. Cable channel placement involves slightly different considerations. Operators place certain services on lower-numbered channels, which helps those services obtain more viewers. This may be an editorial judgment to help viewers select the more valuable program services. Or it may be directed by the sales department to increase the likelihood that local advertising availabilities during, say, an ESPN cablecast, can be sold due to the probably larger audiences on lower-numbered channels. Conversely, cities may desire access channels to be low-numbered to increase their importance. The Act does not empower cities to specify channel position for services, but it does not expressly exclude the practice as part of a negotiated franchise.

So long as a program source subject to a change in channel position remains available to cable subscribers, there is not an absolute diminution in choice as a result of a change. Moreover, depending on the adjacent channels, a higher position might be more advantageous than a lower one. It is argued by cable operators that assigning a public $\mathrm{TV}$ station a position adjacent to higher-numbered science- or arts-oriented channels, rather than where it might appear over the air, helps the station find its intended audience. 
gramming over which it exercises no control. In this capacity it operates as a conduit.

Cable originated as a conduit for broadcast stations. The FCC's must-carry rules required systeins to carry certain local signals. Some of these signals were carried at the system's pleasure. Others, im particular those that dupticated a network signal already being carried or included programs of narrow interest, were undesirable because they took up cliannels the system could use for more popular (or more profitable) satellite program services. While the FCC's prior versions of the inustcarry rules have been deeined unconstitutional, to enjoy the FCC's compulsory, costless copyright in local signals, an operator must carry even voluntarily-agreed-to signals without modifying their advertisimg content. 48

An operator inay also carry programs not of its own choosing on access channels. Access channels are offered on a commercial or noncoininercial basis. Noncommercial public access was one of the early program innovations of cable TV. ${ }^{49}$ Provided free or on an out-of-pocket cost basis, cable systeins allow access use on a first-come, first-served basis.

Access channels were to be an electronic soapbox to promote robust debate and discussion. In practice, public access lias fallen somewhat short. Critics point to shows like the sex-oriented fare of New York City's "Midnight Blue," or to amateurish talk shows hosted by retirees, school children, and others. On the other liand, the cable industry proinotes excellence in local cable access through competition, and there is a substantial national access programming community. ${ }^{50}$ One contribution of public access has been to demystify the television production process, allowing viewers to use low-cost cameras and studios. Given the general public unease over the "power of the nedia," home-grown public

48. 17 U.S.C. $\S 111(b)(3)(1982)$.

49. See Brenner, TV Access: The New Soapbox, 126 AMERICA 477 (1972).

50. The National Federation of Local Cable Programmers is a membership organization that publishes the quarterly Community Television Review. Another organization has stated:

Public access to cable TV is the most viable means remaining today to implement the First amendment. It's the last opportunity citizens have for rcaching a mass audience at an affordable cost. ... Cable Companies cannot function without the invaluable strips of real estate owned by the cities. ... Access channels are a direct quid pro quo, far more valuable to the city than cash alone.

Newsletter of the Public Access Producers Academy 2 (Apr. 1987). Another view was put forward by the chief operating officer of TCI West, Inc., a cable operator: "I don't get particularly excited about idiots coming on screen and doing stupid things because it makes them feel good, but I think community access has a place." California CableLetter, May 1987, at 6. A study of Boston's cable system indicated that more than 25 percent of its subscribers watched at least one program on the system's public access network per month. Brumback, Boston Public Access Net Fares Well in Recent Survey, Multichannel News, May 23, 1988, at 26. 
access television can be an instructive experience, ${ }^{51}$ individually self-fulfilling in the classic first amendment sense. Further, government channels often carry local city council meetings, and educational channels may be used for transmitting programs akin to instructional broadcasting or as a television laboratory for high school or college students.

Leased access, allowing persons unaffiliated with the cable operator to gain access to one or more of the system's channels, follows from a longstanding cable pohicy concept. ${ }^{52}$ However, it has been a small part of the cable environment, generally used by rehigious telecasters and other programmers who buy time on cable systems instead of local broadcasting stations. Apart from video messages, a cable operator may transmit data and voice networks as a tariffed or private carrier. Indeed, it is in this mode that the cable operator intersects with its major potential video coinpetitor, telephone companies. With their established voice and data services, teleplione compamies could, if permitted, expand to include video signals by upgrading their networks to broader capacity fiber optics. 53

As a conduit, the cable operator operates most like a common carrier, indifferent to the communications involved and carrying messages on a first-come, first-served basis. Some of these activities, such as access channels, fulfill regulatory requirements; others, including leased access or data transmission arrangeinents, reflect the voluntary desire of the cable operator to hold itself out as a carrier.

51. One issue not resolved is whether access channels are only for local citizens. Can an out-oftown organization demand the right to use a system's access channel if there is time available? The issue has been raised by nonprofit groups who send video tapes to distant cable systems requesting plays. Arguably, the access channel is for local self-expression tied to an individual, not a franking privilege for non-community-based groups. Access for those groups could occur on leased channels.

52. Most major groups in the early years of cable pohcy analysis, including President Johnson's Task Force on Telecounmunications Pohcy, the Sloan Commission on Cable Communications, and President Nixon's Cabinet Committee on Cable Communications, proposed that cable operators be required to lease some or all of their channels as common carriers. See K. KaLbA, SEPARATING CONTENT FROM CONDUIT (1977). The first amendment aspects of the FCC's leased access requirement of one leased channel, 47 C.F.R. $\$$ 76.254(a)(4) (1979), repealed, 83 F.C.C.2d 147 (1980), were acknowledged but not decided in FCC v. Midwest Video Corp., 440 U.S. 689, 709 n.19 (1979). For a review of leased access after the decision, see D. BRENNER \& M. PRICE, supra note 9, $\$ 6.05(1)$ (b) n.9.

53. Telephone companies are generally barred from providing video programming to those within their telephone service areas, with an exception for rural telephone companies, 47 U.S.C. $\S 533$ (b) (Supp. III 1985). The FCC is considering asking Congress to eliminate these restrictions. F.C.C. Seeks Change So Phone Companies Can Offer Cable TV, N.Y. Times, July 21, 1988, at A1, col. 6. The same restrictions do not apply to power utilities. Nearly 800,000 homes are wired for cable by electric utilities or affiliated companies. See Wolfe, Utilities Plugging into Cable, CaBlEviSION, Feb. 29, 1988, at 17, 17; supra note 13 . 
4. Cable Operator as Franchise Applicant or Operator. When a cable system is entirely located on private property, with no use of public riglits of way or the need to obtain easements from other property owners, there is no need for a franchise. Systems operating in large liotel or apartment complexes ordinarily need no franchise to operate. And thousands of apartinent and condominium buildings operate satellite master antenna television systeins without a franchise. They negotiate with the property owner for the building's "communications riglits." 54

A cable operator who needs access to city property or use of municipal powers to operate stands im a different position. Here, the operator desires two privileges from the city. First, it requires nontransient use of pole and duct space along with the necessary buffer plus, in the case of overliead systenis, air space between pole attachments. ${ }^{55}$ Sucli situations are similar to the lease of a city-owned warehouse or other facility but the government's involvement with the franchise is even greater than its involvement with a warehouse lease because many of the facilities necessary for a franchise are privately owned by telephone companies and utilities, likely (or would-be) conpetitors of the operator, ${ }^{56}$ and access to these facilities must be had at government-regulated rates. ${ }^{57}$ These riglits are akin to other valuable municipal franchise opportunities, such as taxi, food and service concessions. ${ }^{58}$ Just as any property owner might, the

54. The concept of buildings possessing "communications rights" developed in the $1980 \mathrm{~s}$ as builders and landlords began offering communications networks and shared services for tenants. A landlord might offer all tenants "least cost routing" for long distance, using a shared contputer to send a call on whatever long distance carrier offered the lowest tariff for the particular destination and calling period. 1t might also offer less costly access to the local telephone exchange by sharing the number of outside lines among all the building's tenants. In residential complexes, cable TV and such shared tenant services can be nade available. Since the landlord nay not be im a position to operate these communications services itself, selling the right to do so has developed.

55. This nontransient use must be consistent with what the city believes to be in its citizens' best interests. "Wherever the title of streets and parks may rest, they have immemorially been held in trust for the use of the public." Hague v. CIO, 307 U.S. 496, 515-16 (1939); cf. City of Lakewood v. Plain Dealer Publishing Co., 108 S. Ct. 2138, 2152 (1988) (White, J., dissenting) ("It is only common sense that cities be allowed to exert sonie control over those who would permanently appropriate city property for the purpose of ereeting a newspaper dispensing device.").

56. See supra note 53. Ithiel de Sola Pool has written:

The tine will come when broadband digital phone systems can provide the same service as a cable system. When this happens, there will no longer be any need for two feeds into each home, one for voice and one for video. The telephone company will become an obvious carrier for video as well as voice. The issue of cross-ownership restrictions on telephony and cable will then become acute.

I. PooL, supra note 3 , at 52.

57. 47 U.S.C. $\S 224(d)(1)$ (1982).

58. See City of Owensboro v. Cumberland Tel. \& Tel. Co., 230 U.S. 58, 65 (1913). This municipal function dates at least from the early nineteenth century, when corporations, whether municipal or private, were viewed as associations of individuals organized around commercial ends. Frug, The City as a Legal Concept, 93 HARv. L. REv. 1057, 1101-02 (1980). Frug argues that such proprietary activities empower cities, which have over the years become powerless. Id. at 1071-72, 1149-50. 
authority asks, "Which system of franchising and which franchisee(s) will give the best return to the city?"

The return can be measured partly in economic terms. But a pure auction approach, awarding the franchise to the highest bidder, has been made unlawful. 59 So noneconomic considerations arise. In other franchising areas, the makeup of a franchisee's ownership might be a relevant criterion. ${ }^{60}$ In the cable area, particnlarly, these noneconomic considerations might mclude enhancing information diversity ${ }^{61}$ or limiting blight and disruption caused by multiple wirings.

Second, the operator wants to use the city's police power to acquire easements to and between property that, without the franchise, would be available only at the sufferance of each property owner involved. The operator wants to invoke the state's eminent doinain powers, permitting the taking of private property for the public good. Private property owners may be forced to grant access to a franchise holder. ${ }^{62}$ This group of owners imcludes homeowners ${ }^{63}$ as well as utilities, as noted earher. The franchise serves as a one-stop meclianism to acquire necessary rights that

This renewal of city power, he feels, leads to greater participatory democracy. Cable television is an obvious way in which cities gain power and control. A small city can have its own television channel through a public, educational and governmental access channel. Such channels are participatory and portray a sense of city togetherness. They trade the convenience of viewing the proceedings at home against the benefits of citizens actually meeting in town halls or city council chambers.

59. As a practical matter, the FCC outlawed franchises going to the highest bidder early on when it imposed a ceiling on franchise fee auctions and preempted local efforts to deviate from those prescribed limits. Cable Television Report \& Order, 36 F.C.C.2d 143, 209-10 (1972); see 47 C.F.R. $\S 76.31$ (1983) (deleted). The Cable Act caps the franchise fee at five percent. 47 U.S.C. § 542(b) (Supp. III 1985).

60. Many cities refuse to contract with any company that does business in the Republic of South Africa. Other concessionaires may be favored because of physical or economic disadvantage. Minority ownership has been relevant in cable franchising, such as the grant made in Washington, D.C. See infra note 71 .

61. Diversity, both as to ownership of media and as to the resultimg viewpoints, has long been identified as a sustainable basis for content-neutral regulation. See FCC v. National Citizens Comm. for Broadcasting, 436 U.S. 775, 802 (1978); Red Lion Broadcasting Co. v. FCC, 395 U.S. 367, 385, 390 (1969); Associated Press v. United States, 326 U.S. 1, 20 (1944). However, the greatest degree of public satisfaction may not necessarily be associated with more ownership or program diversity, as Steiner and others have demonstrated. Steiner, Program Patterns and Preferences, and the Workability of Competition in Radio Broadcasting, 66 Q.J. EcoN. 194 (1952); see also Owen, Regulating Diversity: The Case of Radio Formats, 21 J. BROADCAsting 305 (1977).

62. Token payment may be required. Loretto v. Teleprompter Manhattan CATV Corp., 458 U.S. 419 (1982).

63. Absent authority to exercise eminent domain through the city's power, laying of cable on private property amounts to a trespass. See, e.g., Devon-Aire Villas Homeowners Ass'n, No. 4 v. Americable Assocs., 490 So. 2d 60, $62-63$ (Fla. Dist. Ct. App. 1985). In Devon-Aire, the Florida District Court of Appeal concluded that cable television was not a public utility under state law and was not entitled to obtain eminent domain. On application for rehearing the court declined to consider the apphication of the 1984 Cable Act. The act empowers cable operators to obtain easements but does not go so far as to declare them public utilities. 
might be otherwise impossible to negotiate individually. Thus, it is the efficient invocation of a city's power to seize those rights at non-inarketclearing prices under a franchise, and not some theoretical license, that a cable operator obtains through a franchise.

Franchising a cable system reseinbles the hicensing of a magazine stand at a municipally owned airport, discussed earher. At the franchising stage in both instances, the question is whether the governmental entity is obtaining the best arrangement it can, in terms of price, service, reliability and product supply. The applicants in both cases seek rights to public or quasi-public property to engage in businesses that involve exercise of editorial discretion, in the one case over which channels to offer, in the other, over which inagazines to stock.

The question becoines inore coinplicated if, say, the applicants consist of a chain owner of bookstores (such as Waldenbooks) and the owner of a Socialist bookstore seeking to expand its operation. The city imght deny the Socialist bookstore equal consideration because of its franchisor's desire to avoid controversy and to ensure that the widest array of mainstream materials are selected. ${ }^{64}$ If the Socialist bookstore wished to distribute materials that would be refused by the winning applicant, the authority inight liave to ensure that sufficient alternatives existed. ${ }^{65}$ However, cable franchising conducted in a nondiscriminatory way as to content does not raise these qualification issues.

Cable franchising is not analogous to newspaper hicensing. Newspaper vendors and trucks make use of city streets, but the use is transitory. Their use does not prevent any other use of the streets. Where newspapers seek nontransitory uses, such as in newsracks, more regulation is permissible, and their exclusion altogether nay be permitted. ${ }^{66}$ It is not

64. Cf. Brown v. Socialist Workers '74 Campaign Comm., 459 U.S. 87, 91 (1982) (Ohio campaign reporting law requiring every political party to report names and addresses of contributors invalid as applied to Socialist Workers Party); NAACP v. Button, 371 U.S. 415, 434-36 (1963) (Virginia law prohibiting organization from retaining a lawyer in connection with hitigation to which it was not a party and in which it had no pecuniary right or hability invalidated as applied to NAACP).

65. See infra notes $168-82$ and accompanying text. In any case, the city could not discriminate against the Socialist store owner because of its views. See supra note 64 .

66. Gannett Satellite Information Network, Inc. v. Metropolitan Transit Auth., 745 F.2d 767 (2d Cir. 1984) (upholding city's power to collect licensing fees for use of newsracks in public train station); cf. City of Lakewood v. Plain Dealer Publishing Co., 108 S. Ct. 2138 (1988) (ordinance regulating placement of newsracks unconstitutional). A more difficult problem, and one closer to cable franchising, arises where soine, but not all, newspapers have access to rack space. Suppose a busy downtown street corner cannot accommodate more than twelve newsracks without endangering pedestrians. Could the city use an auction scheme to determine the twelve occupants, so long as losers in the bidding have adequate, nearby alternatives to vend their papers? Does a first-come, first-served policy or a policy based on distinctions between daily and weekly newspaper pass muster? Cf. Los Angeles Free Press, Inc. v. City of Los Angeles, 9 Cal, App. 3d 448, 88 Cal. Rptr. 605 
the novelty of cable, but an operator's demands on the powers of the city and the easements it requires, that separates it from our bedrock tradition against newspaper licenses.

The cable applicant must engage in arms-length negotiation with the city for rights that it needs to conduct a busmess. The act of franchising does not stop an applicant derned a franchise from expressing a viewpoint.67 It is similar to other lawful demands made by government. For example, a property tax liability might cause an unprofitable cable (or newspaper) operator to shut down. But the tax does not violate the operator's freedom of expression. ${ }^{68}$ Its views may continue to be expressed in otlier forms tlian on a cable system that it happens to own. Indeed, assuming there is a right to expression on cable, access schemes ensure that an excluded operator is not barred from speaking on a cable cliannel in addition to other places. ${ }^{69}$

The real mischief at the franchising stage is not viewpoint discrimination, ${ }^{70}$ but political corruption or bad faith bargaining that makes a mockery of the process. One practice consists of overpromising in response to a city's request for a cable system proposal and then reneging

(1970) (upholding press card issuance policy that included "those directly connected with the regular gathering and distribution of hard core news generated through police and firenan activities" but excluded all others, including the so-called underground press), cert. denied, 401 U.S. 982 (1971). Cable differs in that excluded speakers inay have access to the cable subscriber through another's system; required access to newspapers is forbidden. Miami Herald Publishing Co. v. Tornillo, 418 U.S. 241 (1974).

67. If a franchising decision were based on the apphicant's proposed views, the situation would be entirely different. See infra notes 107-09, $139-42$ and accompanying text.

68. See Minneapolis Star \& Tribune Co. v. Minnesota Comm'r of Revenue, 460 U.S. 575, 583 (1983) (upholding economic regulation of press); cf. Arcara v. Cloud Books, Inc., 478 U.S. 697 (1986) (no first amendinent violation when bookstore closed because of prostitutiou nuisance); see also Avenue Book Store v. City of Tallmadge, 459 U.S. 997, 998-99 (1982) (White, J., dissenting froin denial of certiorari) (stating constitutional standards for nnisance action against bookstore); Califonna ex rel. Cooper v. Mitchell Brothers' Santa Ana Theater, 454 U.S. 90 (1981) (no constitutional requirement of proof beyond reasonable donbt in nuisance action against adult theater).

69. "[O]ne is not to have the exercise of his hiberty of expression in appropriate places abridged on the plea that it may be exercised in some other place." Schneider v. New Jerscy, 308 U.S. 147, 163 (1939); see also Southeastern Promotions, Ltd. v. Conrad, 420 U.S. 546, 556 (1975).

70. There are no reported cases of channel content being the basis, alleged or proven, for grant of a franchise to one party over another. Under the Act, a city may not dennand at the franchising stage (and presumably when requests for proposals are issued) that a particular program service be carried, so the dangers of content-related decisionnaking are reduced. Further, at the pre-franchising stage, which is where Preferred and similar cases have coine to court, there is no evidence that a particular program service will not be made available by a winning operator or that, if not, the service will be unavailable to the audience through leased access channels. The one nonrenewal case striking down exclusive franchising did not involve a clain that a program service was denied. Group W Cable, Inc. v. City of Santa Cruz, 669 F. Supp. 954, 957 (N.D. Cal. 1987); see also infra notes 103-04 and aecompanying text. 
on those promises ${ }^{71}$ after the grant is made and construction has started. ${ }^{72}$ It is arguable whether this is "corruption" or merely unavoidable game-playing common to large-scale government contracts. Cable franchising also has contributed its own abuses. By the mid-1970s, franchise applicants adopted foruns of "rent-a-citizen," offering consultancies to or equities in systems to community leaders in exchange for lending their good nanies or lobbying. ${ }^{73}$ More serious corruption involves bribes to city officials from franchise apphicants. ${ }^{74}$

71. The Cable Act provides for franchise modification relating to facilities or equipment and program services. 47 U.S.C. $\$ 545$ (Supp. III 1985). While the statute governs modifications of existing franchises, see, e.g., Tribune-United Cable v. Montgomery County, 784 F.2d 1227 (4th Cir. 1986), parties may try to scale back commitments that led to a franchise grant. Boston's original franchise called for the operator, Cablevision, to freeze the rate for basic service at $\$ 2.00$ per month for five years, but Cablevision raised the rate to $\$ 6.25$ in the fourth year. Brumback, Cablevision Sues Boston Over Rate-Hike Dispute, Multichannel News, Mar. 28, 1988, at 24. Four years into a franchise contract, Denver cable operator Mile Hi Cablevision eliminated or postponed plans for over \$32 million in facilities and services it had promised. Schley, Denver Urged to Allow Some Mile Hi Cutbacks, Multichannel News, Jan. 20, 1986, at 24. In Washington, D.C., the original grantee was substantially minority-owned, a factor considered in its favor in the grant. Due to financial difficulties, a multiple system operator was brought in, thereby diluting the previously significant minority ownership of the franchisee. And in Oakland, California, the winning bidder promised to charge a price 50\% lower than the next lowest bidder. Once construction was under way, the operator renegotiated the contract to extend the construction deadline, lower the channel capacity, raise the price for additional outlets, and lower the penalty fees for nonperformance of particular contract provisions. Williamson, Franchise Bidding for Natural Monopolies-in General and with Respect to CATV, 7 BELL J. JECON. 73, 92-101 (1976).

72. One study of reneging suggests that it is the result of errors unforeseen at the time a contract is signed. Potential loss of reputation serves as the primary restraint on guileful conduct. $M$. Zupan, Reneging by Cable Operators oll Their Franchise Promises: Opportunism or Economic Necessity? (1984) (available from University of Southern California, School of Business, Department of Finance and Business Economics).

73. In Pacific West Cable Co. v. City of Sacramento, 672 F. Supp. 1322, 1349-50 (E.D. Cal. 1987), a jury found that cable was not a natural inonopoly, that natural monopoly was used as a pretext to award a single franchise and to obtain increased campaign contributions, cash payments and in-kind services. In response to the jury's verdict, the city established a five-year hicense plan for all applicants. One observer stated: '[T] cvidence of increased campaign contributions by cable bidders to city council members and local politicians running for office." KAGAN CABLE TV LAW REP., July 16, 1987, at 3. The forewoman of the six-member jury was reported as stating that the jury made its decision primarily because of the role played by a group of investors of prominent Sacramentans (the "Gang of 73") who had invested in the winning franchise bid: "We felt the way the whole thing was written up was to exclude competition and it had to do with this Gang of 73-and they got their share." Sacramento Bee, July 19, 1987, at 1 , col. 1 .

74. St. Louis Post-Dispatch, Nov. 9, 1984, at 1, col. 1 (St. Louis alderman, president, and other person indicted on federal corruption charges in conneetion with the award of cable franchise). John Zaccaro, husband of 1984 vice presidential candidate Geraldine Ferraro, was acquitted of charges that he acted as an intermediary in seeking a bribe for a city official from a cable operator in return for a New York franchise. Two others involved in the franchises were convicted. Jaffe, NY Jury Acquits Zaccaro of Extortion, Larceny Changes, MultichanNel News, Oct. 19, 1987, at 49. 
Given the actual as well as potential risks of such franchising behavior, and the difficulty of detecting corruption in more subtle guises, the decision to grant an exclusive franchise should be examined thoroughly. ${ }^{75}$ But suppressing speech has nothing to do with these abuses; a corrupt franchise process can and should be voided under the federal due process guarantee or under state anticorruption statutes.

Finally, the right to regulate based on an operator's nontransient uses and city-willed easements differs from a policy based on economic or pliysical scarcity or bhiglit and traffic delays that inay lead a city to exclude a would-be operator. While cities cite these bases to justify franchising, ${ }^{76}$ they may not necessarily be susceptible of clear and convincing proof either way. ${ }^{77}$ Studies suggest tlat the likelihood of longterm, liead-to-liead coinpetition between two cable systems is low, ${ }^{78}$ but the logic of letting cities, rather tlian willing operators, make that decision, may be questioned. Similarly, there is usually rooin physically for an additional operator, if not on existing poles and ducts, then on new ones, built higher or dug deeper. ${ }^{79}$ Blight due to one additional wire

75. Putting the city through a factfinding process may not lead to the discovery of misconduct in the grant process. It is quite possible that the community where the best case for exclusive franchising exists inay also be the place where the process is apt to be most corrupted.

76. These are among the factual issues raised in City of Los Angeles v. Preferred Communications, Inc., 476 U.S. 488 (1986). See infra notes 151-56 and accompanying text.

77. For a critique of these factual considerations, see Bremier, Cable Franchising and the First Amendment: Preferred Problems, Undesirable Solutions, 10 COMM/ENT L.J. — (forthcoming, 1988).

78. One study indicates that for a coinplete overbuilding of an existing system to be profitable, there must be about 110 houses per mile or about 90 houses per mile with very poor reception of over-the-air TV signals. Freeman, Study Finds Profits Elusive When Two Systems Overouild, MuLTICHANNEL NEws, Apr. 13, 1987, at 17 (citing Malarkey Taylor Research, Economic Analysis of Cable Systein Overbuilds (unpublished study for Times Mirror Cable TV) (Jan. 1987)). A study of a potential overbuild in St. John's County, Florida, in 1987 indicated that a full overbuild would not be economically viable. A cream-skim overbuild directed at only lucrative and more densely populated developments could be profitable, although it would lead the incumbent provider or overbuilder quickly to sell out, leaving the land developer, not the residents, to choose the ultinate operator. Malarkey Taylor Assocs., Economic Analysis of an Overbuild in St. John's County Fla. (July 24, 1987). A study for Metro-Dade County, Florida, reached similar results. Touche Ross, Report on Overlapping Cable Franchise Study (Oct. 7, 1987). Thomas Hazlett has convincingly criticized the theoretical shortcomings of a natural inonopoly theory for cable based on the absence of that theory's consideration of economies of density, critical to determining whether competition can survive. Hazlett, Private Monopoly and the Public Interest: An Economic Analysis of the Cable Television Franchise, 134 U. PA. L. REV. 1335, 1340 (1986).

79. The physical scarcity argument for newspapers differs froin the one advanced in the cable context. A hypothetical shortage of newsprint or ink during a national emergency might justify some regulation of supply. Consider the reputed shortage of red dye during World War II, leading the inanufacturers of Lucky Strike to change the packaging froin red to green under the advertising slogan, "Lucky Strikes go to war!" Any application of rationing, however, inust occur in a contentneutral way. Cf. City of Lakewood v. Plain Dealer Publishing Co., 108 S. Ct. 2138, 2159 (1988) (White, J., dissenting). 
invites quite subjective assessment, while delays in traffic could be remedied if competing franchises had to lay wire simultaneously, ${ }^{80}$ or await some other scheduled traffic disruption or particularly congested streets. Resolution of these questions, however, does not change the character of a franchise as a city's bestowal of an economic benefit on an operator.

The argument may be made that the city should charge the value of these benefits, or the cost of disruptions, as a condition of a franchise, but it should not absolutely refuse to grant a franchise. While this approach is surely permissible, placing a value on the exercise of eminent domain is nearly impossible: if one were to survey affected residents, some property owners might be hold-outs, making the actual market value of the power incalculable. Moreover, should telephone companies be allowed to provide cable television (or electrical utilities more interested in providimg cable), they might be unwilling to grant access at any price unless required.

Second, whether or not multiple grants are desirable-and they may be-the constitutional question is really whether the first aniendment requires cities to take this approach. The response depends on whether the opportunities for expression remaming for the rejected franchisee after a franchise denial are sufficient and whether the audience's speech interests are likely to be impaired as a result of the denial. As will be seen, the answer is that the speech impact of exclusive franchising, given access, is not very significant.

\section{The Cable Act: Its Treatment of the Operator's Right OF EXPRESSION}

How is the foregoing model of cable service addressed in the 1984 Cable Act? The Act is not structured around the functional approach just reviewed, for it was designed to acconiphish many objectives besides articulating those interests. But it does, indirectly, speak to the differentiated rights of cable operators.

\section{A. Background of the Act.}

The 1984 Cable Act was passed at a time when, as the acconipanying legislative history states, "[m]umicipal authority to franchise and regulate cable television [had] been under an mcreasing number of

80. And if cities can be required to suffer the visual problem of strewn paper, see Schneider v. New Jersey, 308 U.S. 147 (1939), cables in the air seem less burdensome. Note, incidentally, that the handbills in one of the four cases on review in Schneider contained the words "Admission 50 and

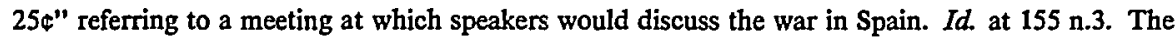
Court, however, did not distinguish this handbill from the others, suggesting that the commercial aspect of the message did not remove its protection. 
challenges on three fronts: in the courts, at the Federal Communications Commission, and at the state pubhic utility commissions."81 The Act responded to the challenges by "preserv[ing] the critical role of inunicipal governments in the franchise process, while providing appropriate deregulation in certain respects to the provision of cable service." 82

The Act reflected a conipromise acceptable to the two inajor groups most affected by the legislation, the National Cable Television Association and the National League of Cities (representing the interests of franchisors), although other groups, governmental agencies and imdividuals were involved. ${ }^{83}$ It principally embodies the House of Representatives' version of the bill, and the Report acconpanying it constitutes the principal record of congressional imtent. ${ }^{84}$

It would be maccurate to describe the Act as a result of legislative capture by either the cable imdustry or the cities. ${ }^{85}$ Its passage was not a subject of unamimity among the imdustry. Some cable industry leaders decried the proposed law and contimue to beheve it a serious legislative loss. ${ }^{86}$ The cable imdustry was succeeding admimistratively at the FCC

81. H.R. REP. No. 934, 98th Cong., 2d Sess. 19, reprinted in 1984 U.S. CoDE CoNG. \& ADMIN. NEws 4655,4656 . The FCC had engaged in significant preemption of certain aspects of local regulation prior to the Act's passage, adding to uncertainty about the extent of municipal authority. See In re City of Miami, Fla., 56 Rad. Reg. 2d (P \& F) 458 (1984) (1nem.) (limiting city's franchise fce authority); In re Community Cable TV, Inc., 98 F.C.C.2d 1180, aff'g 54 Rad. Reg. 2d (P \& F) 1351 (1983) (preempting state and local regulation on program service choice and pricing). No challenge, however, was made to the right to grant franchises. See D. BRENNER \& M. PRICE, supra note $9, \S 2.05$.

82. H.R. REP. No. 934, supra note 81 , at 19 , reprinted in 1984 U.S. CODE CONG. \& ADMIN. NEws at 4656 .

83. L. Powe, supra note 43, at 232-33.

84. The Senate's cable bill, S. 66, 98th Cong., 1st Sess., 129 CoNG. REc. S8325-28 (daily ed. June 14, 1983), passed a year earlier, see 129 CONG. REC. $\$ 8325$ (daily ed. June 14, 1983), was in most respects the same piece of legislation.

85. See Wiley, A Capture Theory of Antitrust Federalism, 99 HARv. L. REv. 713, 723-27 (1986), and authorities cited therem. Drawing from M. Olson, The Logic of Collective AcTiON 29 (1965), the "capture" theory, generally speaking, posits that government intervention in markets occurs not to further consumer interest. Instead, government acts at the behest of private interests, principally producers, who have captured the government agency or legislature, inducing it to develop laws inuring to their benefit. In the cable context, both the cable industry and the cities could be viewed as "producers," each desirous of obtaining the best arrangement for itself, e.g., a high renewal expectancy for the operators and a high franchise fee for the cities. One of the "producers," a city official, is supposed to represent the interests of consumers, subject to ouster from office if she fails to serve that interest. Moreover, unlike rewards taken by private entities, the franchise fee is not a private benefit won at the expense of the public. Given the veto power possessed by cities in these negotiations and their apparent satisfaction at the outcome of the legislation, a capture analysis would seem to be unavailing here. For a description of the parties' last-minute settlement, see Back to the Brink for Cable Bill, BROAdCasting, Oct. 1, 1984, at 39.

86. See, e.g., Schildhause, Preferred Communications: Preamble to Breakup of Local Cable Franchising?, 7 PACE L. REV. 1, 21-23 (1986) (passage of Act complicates task of establishing cable's first amendment rights). 
on many of the issues resolved by the legislation, ${ }^{87}$ and there is reason to beheve that short-term results even more favorable to cable, even if still subject to legislative undoing, might have been produced there. Similarly, from the cities' perspective, the Act embodied significant preemption of their power over some franchise terms that would have governed operators. The Act, however, resolved major issues of contention and uncertainty for both sides, and this advantage outweighed the perceived losses from compromise. It gives explicit approval for city franchises, requires a franchise grant as a precondition to offermg cable service, ${ }^{88}$ and limits franchise fees. ${ }^{89}$ It establishes procedures for franchise renewal ${ }^{90}$ and places limits on what cities may exact in a franchise. ${ }^{91}$ It frees most cable systems from rate regulation ${ }^{92}$ and provides a system of leased access for persons unaffiliated with an operator. ${ }^{93}$

Competing first amendment considerations sound in the legislative history. ${ }^{94}$ Particularly, the $A_{1}$ ct accounts for the interests of operators as well as those who might wisli to commumicate by cable but do not possess a franchise. Also evident is Congress's felt need to clarify the lines of federal, state, and local authority over cable.95

87. See, e.g., In re Community Cable TV, Inc., 98 F.C.C.2d 1180 (1984), aff'g 54 Rad. Reg. $2 \mathrm{~d}$ (P \& F) 1351 (1983) (preempting local rate regulation of all satellite-delivered signals). The Commission in 1984 had begnn to move away from the "deliberately structured dualism," dividing authority between federal and local authority, set forth in the Cable Television Report and Order, 36 F.C.C.2d 143, 207 (1972). Partly, this change in attitude was generated by the Court's broad grant to the FCC of preemptive authority over cable matters in Capital Cities Cable, Inc. v. Crisp, 467 U.S. 691 (1984).

88. 47 U.S.C. § 541(b) (Supp. III 1985). The Senate version of the Cable Act provided that no common carrier regulation could be imposed on a cable system. The accompanying Senate report stated that "cable is neither a monopoly service nor is it an essential service, which are the two traditional tests of common carrier or utility status." S. REP. No. 67, 98th Cong., 1st Sess. 29 (1983). The Act provides that a cable operator is not deemed a common carrier when it provides "any cable service." 47 U.S.C. § 541(c) (Supp. III 1985).

89. 47 U.S.C. $\S 542(b)$ (Supp. III 1985).

90. Id. § 546 .

91. Id. § 544.

92. Id. § 543.

93. Id. § 532(c).

94. See H.R. REP. No. 934, supra note 81, at 31-36, reprinted in 1984 U.S. CoDE CoNG. \& ADMIN. News at $4668-73$.

95. This degree of federal detail as to municipal conduct is remarkable. Rather than expressly granting power to regulate to the states or setting out federal franchising standards (as it does with leased access in particular), the Act dictates a federal policy over municipal conduct. This approach is a twist on the supremacy clause, which requires that federal law supersede state regulation where national uniformity is required. U.S. CoNST. art. VI, cl. 2. Instead of direetly governing, Congress regulates cable by setting parameters for cities. But cf. 33 U.S.C. $\$ 1311$ (1982) (setting forth congressional standards for effluent limitations under the Clean Water Act that apply to water treatment facilities principally operated by municipalities). It also reverses the trend of some cases and commentary stressing cities' lack of inherent sovereignty. See, e.g., Community Communications Co. v. City of Boulder, 455 U.S. 40 (1982) (municipalities not immune from antitrust laws); City of 


\section{B. The Expressive Activities of Cable Under the Act.}

1. Cable Operator as Speaker. The Cable Act makes little mention of the editorial rights of the cable operator, although there is an awareness of those rights. For instance, the House Report accompanying the legislation refers to the "First Amendment riglits of the cable operator."96 This lack of reaffirmation is not surprising, since these rights are already einbodied in the first amendment. The cable industry might liave preferred greater clarification, but Congress, faced witl no developed law on cable's first amendment status, took the path of least resistance and avoided setting precise definitions.

Even so, the Act indirectly affirms that cable operators are to enjoy broad editorial freedom. It does so indirectly by autliorizing lock box requirements for subscribers who want to "restrict the viewing of programming which is obscene or indecent." 97 The evident assuinption of this provision is that cable inay carry even indecent programming subject to a lock box. ${ }^{98}$ Further recognition of the cable operator's editorial freedom appears in the Act's limitation on the number of cable cliannels for commercial use that an operator must provide. ${ }^{99}$ Cable operators are not to be pure carriers on all cliannels, only on a few. When an operator is deemed to be a carrier, it is relieved of legal responsibility for the content of programming.

At one point, the Act distinguishes between a cable "operator" and a cable "programmer." This occurs in the provision retaining an opera-

Lafayette v. Louisiana Power \& Light Co., 435 U.S. 389 (1978); see Frug, supra note 58, at 1062-80; Williams, The Constitutional Vulnerability of American Local Government: The Politics of City Status in American Law, 1986 WIS. L. REv. 83; Williams, The Invention of the Municipal Corporation: A Case Study in Legal Change, 34 AM. U.L. REv. 369 (1985).

These statute-based powers differ from the general franchising power granted by state constitutions to many municipalities under "home rule" authority. For example, in Colorado, city authority derives directly from the home rule provisions in "the state constitutiou and is not a residual or delegated power." Community Communications Co. v. City of Boulder, 630 F.2d 704, 707 (10th Cir. 1980), rev'd on other grounds, 455 U.S. 40 (1982); see CoLo. CoNST. art. XX, § 6. This leads to the intriguing result that the Cable Act preempts state constitutional home rule provisions to the extent they authorize municipal activitity uo longer permitted by the Act. See 47 U.S.C. $\S 556$ (Supp. III 1985).

96. H.R. REP. No. 934, supra note 81 , at 31 , reprinted in 1984 U.S. CODE CONG. \& ADMIN. NEWs at 4668.

97. 47 U.S.C. $\$ 544$ (d)(2)(A) (Supp. III 1985). This provision must be read in conjunction with another part of the Act that specifies that transmitting obscenity on cable is a crime. Id. $\S 559 ; c f$. id. $\S 558$.

98. And it reaffirms decisions finding the lock box a sufficient protection agaiust unwanted exposure to indecent programming.

99. H.R. REP. No. 934, supra note 81 , at 48, reprinted in 1984 U.S. CODE CONG. \& ADMIN. NEWS at 4685. 
tor's or programner's hability for defamation, obscenity and the like. ${ }^{100}$ "Cable operator" is defined in the Act; 101 "cable programmer" is not. This lapse in the Act is unfortunate; nevertheless, the House Report accompanying the Act defines programmers to include "parties that exercise control over the content of programs." 102 When a cable operator acts in its capacity as a programmer, it coines closest to the first amendnient protection traditionally provided to speakers. Einphasis on this definition would have accentuated this point, evidenced through the other provisions of the Act, that the cable operator is soinetimes, but not always, exercising editorial control.

2. Cable Operator as Program Selector. The Cable Act establishes few restrictions on a cable operator's right to select programs. It grandfathers existing progranı service provisions, ${ }^{103}$ but future franchises-new or renewal-inay not require particular video programming or other information services. ${ }^{104}$ Requireinents for "broad categories of video programming or other services," however, are enforceable. ${ }^{105}$ Applymg these two requireinents, a franchisor may insist, for example, that a "news" or "music video" channel be provided, but it may not naine the particular program service.106

The autonoiny of the operator's prograin selection, insulated at the franchise issuing stage, is also protected at renewal time. A city inay deny renewal of a cable franchise, but inay not take into account "the inix, quality, or level of cable services or other services provided over the system" in reaching its judgment. ${ }^{107}$ This provision appears to apply both to franchises granted before and after enactınent. ${ }^{108}$ The undeniable

100. 47 U.S.C. $\S 558$ (Supp. III 1985). Botli operators and programmers are relieved from liability for speecl on access channels because tliey exercise no control there. Id. $\$ \S 531(\mathrm{e}), 532(\mathrm{c})(2)$. 101. Id. $\S 522(4)$.

102. H.R. REP. No. 934, supra note 81, at 95, reprinted in 1984 U.S. CoDE CoNG. \& ADMIN. NEws at 4732. The report adds, confusingly, that the definition "would not only include program producers to the extent this would be consistent witl applicable Federal, state and local law." Id. The point apparently being made is that entities other than producers exercise editorial control. For instance, HBO does not produce inost of its schedule but would still be a cable programmer under the report's definition. Sinilarly, governmental, educational or public groups that inaintain editorial control over the content of access clrannels would also be covered, unless immunized by soine other law.

103. 47 U.S.C. $§ 544$ (Supp. III 1985).

104. Id. $\S 544(\mathrm{~b})(1)$.

105. Id. $\S 544(\mathrm{~b})(2)(\mathrm{B})$.

106. In addition, a franchise inay specify that the operator not carry "obscene or . . otherwise unprotected" cable services. Id. $\$ 544(\mathrm{~d})(1)$.

107. Id. $\S 546(\mathrm{c})(1)(\mathrm{B})$.

108. The Act's procedural safeguards for renewal applicants call for a two-stage proceeding, beginning as early as three years before a franclise expires. Id. $\S 546(\mathrm{a})$. It is not clear low Congress intended to treat operators whose franchises expire prior to the time when the operators can 
result is that the Act forbids a cable operator's choice of program services to be the basis for franchise grant or renewal. ${ }^{109}$ Thus, the mixed commercial and editorial character of program selection by an existing franchisee is resolved in favor of protecting operator choice.

However, while the Act does not permit a city to specify program services, the law regulates the number of services that may be offered. It does so by mandating that the operator dedicate a number of channels for leased access, the number varying with system size. In addition, by permitting cities to require noncommercial access channels, the Act potentially further limits the number of programmable channels.

3. Cable Operators as Distributors for Other Speakers. The Cable Act provides that the operator shall be treated as a carrier in situations involving the expressive interests of those not affiliated with the operator. The Act explicitly adopts the view that the cable operator is not a first amendınent speaker on channels reserved for access.

The leased access provisions of the Act are Congress's inost direct attempt to shape the cable editorial landscape. Unlike the negotiable public access or channel category requirements, the leased access requirement is a direct charge from the Act on the operator. Systems with 36 or more channels must offer 10 percent-and systems with 55 channels or more, 15 percent-of their channels for leased commercial use by "persons unaffiliated with the operator". ${ }^{110}$ The goal is to "assure that the widest possible diversity of information sources are made available to the public ... in the inanner consistent with growth and development of cable systems." 111 Leased access is a recognition of cable's conduit function for programmers who do not operate a franchise. Access removes operator editorial control over a limited number of channels, ${ }^{112}$ and allows third parties sufficient channels to offer program services that "compete with existing cable offerings or are not otherwise offered by the cable

enjoy the procedural protections of the Act's renewal provisions. It would be reasonable to apply those safeguards that can be invoked, such as the restriction on program review, even if other protections cannot be.

109. In discussing the renewal provision, the House Report states:

The "service" encompassed by this provision is not the quality or level of particular programming services or other cable services which the operator has provided. "The quality of the operator's service" does refer to the services associated with day-to-day operation (e.g., response to consuiner complaints [sic] signal quality billing).

H.R. ReP. No. 934, supra note 81, at 74, reprinted in 1984 U.S. CODE CONG. \& ADMIN. NEws at 4711 .

110. 47 U.S.C. $\S 532(b)(1)$ (Supp. III 1985). Eighty percent of cable subscribers reportedly have cable systems with 36 channels or more. Cable Statistics, Broadcastrng, Oct. 12, 1987, at 42.

111. 47 U.S.C. $\$ 532$ (a) (Supp. III 1985).

112. H.R. REP. No. 934, supra note 81 , at 50, reprinted in 1984 U.S. CODE CONG. \& ADMIN. NEWS at 4687. 
operator (for political reasons, for instance)."113

In addition to mandatory commercial access, the Act allows franchisors to require a cable operator to set aside channels for public, educational, and governmental (PEG) use. ${ }^{114}$ The Act reheves the operator from the financial burden of access somewhat, allowing an offset from the franchise fee for expenses to support or capitalize access facilities, depending on when the franchise was granted.115 An operator may not exercise any editorial coutrol over a PEG channel and is immunized from liability for what is carried on those channels (as well as leased access channels). ${ }^{116}$ Significantly, franchisors who require PEG access must allow the operator to redeploy unused access channels to other uses. ${ }^{117}$ The Act does not define who qualifies for access on "educational" or "governmental" channels, and the House Report sheds no light on those defimitions.

The Act also conteinplates that cable operators may desire to offer communications services other than video cable service and that such common-carrier-like service might come under the authority of state public utility commissions or the FCC. The Act permits such regulation, in particular allowing appropriate regulatory authorities to require cable operators to file informational tariffs for nonprogram services. ${ }^{118}$

4. Cable Operator as Franchise Applicant. The Cable Act grants cities discretion to determine the number of cable operators that they will authorize in any particular geographic area. In particular, a city can choose to grant one exclusive franchise to one operator. ${ }^{119}$ Grant of a de facto exclusive franchise is tied, in the same subsection of the Act, to an operator's right to construct the cable system over rights of way and through necessary easements that have been dedicated to compatible

113. Id. at 30, reprinted in 1984 U.S. CODE CONG. \& ADMIN. NEWS at 4667.

114. 47 U.S.C. $\S 531$ (Supp. III 1985).

115. Id. $\S 542(\mathrm{~g})(2)(\mathrm{B})-(\mathrm{C})$.

116. $I d . \S 558$.

117. $I d . \S 541(\mathrm{~d})(1)$.

118. Id. $\S 541(\mathrm{~d})(1)-(2)$.

119. Id. $\$ 541(\mathrm{a})(1)$. One interpretation of the language "A franchsing authority may award ... 1 or more franchises" is that Congress did not want to decide whether exclusive grants are constitutional, particularly since the House Report expressly passed no judgment on the antitrust aspects of exclusive grants. H.R. REP. No. 934, supra note 81, at 59, reprinted in 1984 U.S. CODE CONG. \& ADMIN. NEwS at 4696. Thus the Act could be sustained if the provision is read to simply describe the franchising process that inight or might not lead to a single grant, depending on who applied. But the House Report supports the view that exclusive grants were contemplated when it indicates that this provision "grants to the franchising authority the discretion to determine the number of cable operators to be authorized to provide service in a particular geographic area." Id. (ennphasis added). This passage bothered the Ninth Circuit in Preferred Communications, Inc. v. City of Los Angeles, 754 F.2d 1396, 1411 n.11 (9th Cir. 1985), aff'd, 476 U.S. 488 (1986). 
uses. ${ }^{120} \mathrm{~A}$ cable franchisee is to enjoy the same rights as to rights of way and easements as "other utilities." 121 Together these provisions associate a franchise, possibly exclusive, with the valuable rights that the cable operator needs to construct and operate a cable system.

The Act does not specify how the franchise selection process should operate, other than to insist that grants not result in denial of cable service based on the income of residents in the area to be served. ${ }^{122}$ The Act might have insisted otherwise. A nonexclusive franchise approach, requiring cities to issue a license to any party who meets minimum financial requirements, could have been mandated. Or the Act could have provided that, again subject to certain minimum qualifications, the franchise be awarded by lottery. ${ }^{123}$ Instead, the Act leaves to the franchising authority discretion as to the number of franchise grants. Thus, while the Act grants extensive editorial protection over program selection to an operator in possession of a franchise, it does not require that all who miglit be pliysically accommodated on poles and ducts be granted a franchise. The Act's franchising provisions cast applicants in primarily a commercial rather than editorial light, as entities, like "other utilities", seeking valuable grants from the city. ${ }^{124}$ Editorial rights of excluded speakers, including would-be franchisees, are addressed through the leased and public access provisions of the Act.

120. 47 U.S.C. $\$ 541(a)(2)$ (Supp. III 1985).

121. H.R. REP. No. 934, supra note 81 , at 59, reprinted in 1984 U.S. CODE CONG. \& ADMIN. News at 4696 ("Any private arrangements which seek to restrict a cable system's use of such easements or rights-of-way which have been granted to other utilities are in violation of this section and not enforceable."). Cable operators have an imphed right of action to file suit under seetion 541(a)(2). Ceutel Cable Television Co. v. Admiral's Cove Assocs., 835 F.2d 1359, 1361 (11th Cir. 1988).

122. 47 U.S.C. $\$ 541$ (a)(3) (Supp. III 1985).

123. Cf. id. $\S 311$ (d) (authorizing FCC selectiou of mass media hicenses by weighted lottery).

124. In dissenting from the Court's opimion declaring unconstitutional a statute giving a mayor unbridled discretion over issuing permits for newsracks, Justice White rejected a first amendment focus to characterize the question:

Appellee resists this "characterization" of its placement of newsboxes on city property, arguing that it is not seeking to "ren[t]" or have "permanently set aside" portions of the sidewalk for its news racks. ... Rather, appellee contends, it is merely seeking to exercise its "First Amendment right" to distribute newspapers by means of a newsrack, "the meehanical cousin" of the traditional means of selling papers on city streets, the "newsboy." ... This "characterization" of its activities is unpersuasive. . . . The character of the newsrack's intrusion on city sidewalks is not lessened by the fact . . . that the purpose of the "taking" is the communicatiou of ideas.

City of Lakewood v. Plain Dealer Publishing Co., 108 S. Ct. 2138, 2155 n.6 (1988) (White, J., dissenting). 


\section{AsSessing THE ACT'S TREATMENT OF OPERATOR RIGHTS UNDER THE FIRST AMENDMENT}

As noted, the Act does not differentiate among the operator's separate functions. It does not, for example, specify the degree of protection an operator should enjoy when it is acting as a cable programmer, consciously engaged in expressive activities. Nor does its legislative history provide an explicit judgment that cable operators actimg as programmers are entitled to the same protection afforded to newspaper pubhishers. Nevertheless, there are indications that the Act recognizes the varied characterizations of the cable operator specified in the model. By negative implication, the operator enjoys autonony from the franchising authority in program channel selection. ${ }^{125}$ The Act recognizes cable's distributive function as well as the proprietary character of a franchise. The constitutional question is: does the Act's conclusions about these matters conflict fundainentally with the development of first ainendment law in other contexts? ${ }^{126}$

\section{A. The Cable Act's Phantom First Amendment Problem.}

The search for the central meaning of the first ainendinent is like a tour of the Wimchester Mystery House. All persons enter through soine doors, but other doors have meaning for a few even if they lead to nowhere. ${ }^{127}$ John Stuart Mill set forth a principle that enjoys wide acceptance: government should not be entitled to a monopoly over what ideas or arguments the public hears. ${ }^{128}$ This concept of a marketplace of ideas recognizes two tenets of a democratic state: government is not infallible, and government cannot be the only provider of news and information. ${ }^{129}$

125. The PEG and leased channels are exceptions to this autonomy. See supra notes 114-17 and accompanying text.

126. Kalven, Broadcasting, Public Folicy and the First Amendment, 10 J.L. \& EcoN. 15, 38 (1967) ("Law, it has been said, is determined by a choice between competing analogies.").

127. The Winchester Mystery House, San Jose, Cal., was designed to baffle the evil spirits that haunted Sarah Winchester, heiress to the rifle fortune. The owner and servants needed maps to find their way. It contains 160 rooms, 2000 doors, 13 bathrooms, 10,000 windows, 47 fireplaces, 40 staircases, blind closets and secret passageways. Automobile Club of So. CAL. (AAA), CALIFORNIA-NEVADA TOUR BOOK 129 (1988 ed.).

128. J.S. MiLL, ON LIBERTY 18 (D. Spitz ed. 1975). Mill's view was not based on some assumption that truth would emerge in the marketplace of ideas, but that when government acts to suppress speech secmingly because it is false, it may in fact be acting to repress minority views. See M. NiMMER, NimMER ON FREEDOM OF SPEECH $§ 1.02$ [A] (1984) (repression of speech precludes potential "enlightenment" by new thought or data); Karst, Equality as a Central Principle in the First Amendment, 43 U. CHI. L. REv. 20 (1975) (discussing hiberty of expression); see also F. SCHAUER, Free SpeEch: A PhILOSOPHICAL ENQUiRY 80-86 (1982); Schauer, Language, Truth and the First Amendment: An Essay in Memory of Harry Canter, 64 VA. L. REv. 263, 268-76 (1978).

129. Promoting a marketplace of icleas found support in the earliest articulations of modern first amendment thought. Justice Holmes and Justice Brandeis argued that "the best test of truth is the 
Where one of the inass media, including cable, is concerned, suppression of speech not only offends the medium as a speaker, but also debilitates it as an informer of histeners or readers. The state should not be allowed to use its police power to ban ideas or silence voices.

Beyond this general view, a wide spectrum of views exists as to the first amendment's purpose and the proper inethodology for resolving concrete cases. ${ }^{130}$ Protecting citizens by promoting an informed electorate is often cited as a chief goal, but it is by no means the only goal. ${ }^{131}$ Ensuring individual self-fulfillment and the development of our human

power of the thought to get itself accepted in the conpetition of the market." Abrams v. United States, 250 U.S. 616, 630-33 (1919) (Holmes \& Brandeis, JJ., dissenting) (disagreeing with majority holding that the first amendnent did not protect the wartine publishing of pamphlets critical of President Wilson's decision to send troops to help counter the Russian Revolution). It was also stressed by Judge Learned Hand in his classic formulation in which he identified "the dissemination of news from as nuany different sources, and with as many different facets and colors as it is possible" as the interest protected by the first amendment; "it presupposes that right conclusions are nore likely to be gathered out of a multitude of tongues, than through any kind of authoritative selection." United States v. Associated Press, 52 F. Supp. 362, 372 (S.D.N.Y. 1943), aff'd, 326 U.S. 1 (1944); see Gunther, Learned Hand and the Origins of Modern First Amendment Doctrine: Some Fragments of History, 27 STAN. L. REV. 719 (1975).

130. See Shiffrin, The First Amendment and Economic Regulation: Away from a General Theory of the First Amendment, 78 Nw. U.L. REv. 1212 (1983); Schauer, Codifying the First Amendment: New York v. Ferber, 1982 Sup. Cr. REv. 285, 317.

131. Alexander Meiklejohn limited the narket of ideas to where protected speech is tied to the role of citizens as voters. In Meiklejohn's formulation, the guarantee of free speech apphies to con1munication "which bears, directly or imdirectly, upon issues with which voters have to deal-ouly, therefore, to the consideration of nuatters of public interest." A. MEIKLEJOHN, FREE SPEECH AND ITS RELATION TO SELF-GOVERNMENT 94 (1948). Speech not protected under the first amendment receives protection under the due process clause of the fifth amendment, according to Meiklejoin, see id. at 37-39, or the due process clause of the fourteenth amendment. See id. at 59-61; see also Wellington, Freedom of Expression, 88 YALE L.J. 1105 (1979) (discussing Meiklejohn's views). Meiklejohn attempted to draw a hine between speech that deals with the public welfare of the community proteeted by the first amendmene and speech relating to the private good of the individual citizen, which he said went unaddressed by that amendnent. This lime was endorsed to varying degrees by Alexander Bickel and Robert Bork, A. BICKEL, THE MORALITY OF CONSENT 62 (1975); Bork, Neutral Principles and Some First Amendment Problems, 47 IND. L.J. 1, 27 (1971) ("If the dialectical progression is not to becone an analogical stampede, the protection of the first amendment ... nust be cut off when it reaches the outer limits of pohitical speech."), although Judge Bork testified during his confirmation hearings that he accepted the Court's view that "First Amendment protection applies to moral discourse . . . scientific speech . . . news . . . opinion . . . hterature." TIME, Sept. 28, 1987, at 18. Meiklejohn's view has not been accepted by the Court. See Abood v. Detroit Bd. of Educ., 431 U.S. 209, 231 (1977). But compare FCC v. Pacifica Found., 438 U.S. 726, 742-51 (1978) with id. at 761 (Powell, J., concurring in part and concurring in the judgment) ("I do not join Part IV-B [of Justiee Steven's opinion] because I do not subscribe to the theory that the Jnstices of this Court are free generally to decide on the basis of its content which speech protected by the First Amendment is most 'valuable' and hence deserving of the most protection, and which is less 'valuable' and hence deserving of less protection."). But see City of Renton v. Playtime Theatres, Inc., 475 U.S. $41,48-49$ (1986). The fundamental problem with the self-governance view is that it leads the state ultimately to determine what should be said, short-circuiting the freedom supposedly guaranteed. Meiklejohn seemed to realize this point. In later writings, he categorized speech in ways that strain the application of "self-governance." Meiklejohn, The First Amendment is an Abso- 
potential, ${ }^{132}$ operating as a safety valve to foster stability and orderly change, ${ }^{133}$ and checking the power of political leaders ${ }^{134}$ are all cited to explain the purposes of the freedom of expression. Further, first amendment theory may embrace the need for affirmative efforts to include speakers and viewpoints as well as the need to shield speakers from government regulation. ${ }^{135}$

Whatever weights one assigns to each of these goals, identification of one or inore of these speech-related interests is necessary to explaim why the heightened judicial scrutiny applicable to a first amendment claim obtains in a particular instance. The first amendment does not protect any utterance or activity that someone calls speech. ${ }^{136}$ "Low-value" categories of speech-for example, defamation, "fighting words," perjury and obscenity-have been placed outside of the first amendment's protection. Whatever categorization is proper, ${ }^{137}$ the overriding poimt is that the first ainendment at the outset requires the presence of a protectable speech interest. ${ }^{138}$

lute, 1961 SuP. CT. REv. 245, 262-63 (finding novels, paintings, and dramas, even those that frankly portray sexual experiences, to be entitled to first amendment protection).

132. C. Edwin Baker holds individual self-fulfillment and advocacy of change, which he calls the "liberty model," "the most coherent theory of the First Amendment." Baker, Scope of the First Amendment Freedom of Speech, 25 UCLA Z. REV. 964, 966 (1978). Pursuit of this goal leads to a focus on the personal, the individual, without regard to whether the speech involved addresses matters of governance. Its shortcoming is that it tends to deny first amendment protections to corporate speech, which the Court has definitively provided. First Nat'1 Bank v. Bellotti, 435 U.S. 765 (1978). But cf. FEC v. Massachusetts Citizens for Life, Inc., 107 S. Ct. 616, 631 (1986). See generally M. Nimmer, supra note 128, $\S \$ 1.02-1.04$; T. EMERSON, THE SYSTEM OF FREEDOM OF EXPRESSION (1970).

133. As Justice Brandeis observed in Whitney v. California, "it is hazardous to discourage thought, hope and iunagination; that fear breeds repression; that repression breeds hate; that hate menaces stable government; that the path of safety hes in the opportumity to discuss freely supposed grievances and proposed remedies; and that the fitting remedy for evil counsels is good ones." 274 U.S. 357, 376-77 (1927) (Brandeis, J., concurring).

134. Blasi, The Checking Value in First Amendment Theory, 1977 AM. B. Found. REs. J. 521.

135. Thus, for example, Owen Fiss would view the purpose of the first amendment to ensure and enrich the public debate, which may collide with the view that the first amendment only protects speaker autonomy. Under this view, private parties may be as great a threat to freedom of speech as government. The first amendment in Fiss's view would force owners of shopping centers to allow access for pamphleteers. Fiss, Free Speech and Social Structure, 71 IowA L. REv. 1405, 1414-15 (1986). Others, led by Jerome Barron, suggest that private speakers of major mass inedia that nse the radio spectrum, such as CBS, should be treated as public forums, which creates a right of access. J. Barron, Freedom of the Press for Whom? The Right of Access to Mass Media (1973).

136. J. Ely, DEMOCraCY AND DisTrust 109 (1980).

137. Compare Redish, The Content Distinction in First Amendment Analysis, 34 STAN. I. REV. 113 (1981) with Farber, Content Regulation and the First Amendment, 68 GEO. L.J. 727 (1980).

138. The case law as to cable and the first amendment, particularly that which addresses the question of exclusive franchising, has largely been devoid of this traditional analysis, which ties the availability of protection to the existenee of a protectable speech interest. This omission makes what is said about cable and the first amendment in those cases quite unhelpful. See, e.g., Group W Cable, Inc. v. City of Santa Cruz, 669 F. Supp. 954, 960-61 (N.D. Cal. 1987). It is understandable that not 
The courts reserve their most exacting scrutiny for regulations that are based on the content of particular speech, generally invalidating them under so-called "track one" analysis. ${ }^{139}$ Although the Cable Act regulates obscemity and other categories of speech found unprotected by the Constitution, ${ }^{140}$ there is no other direct content regulation of any kind im the Act. ${ }^{141}$ Thus, no matter to which strands of first amendment theory one attaches key importance, the Act does not discriminate on the basis of content. Were it to include directives to regulate otherwise protected content of cable programs, there could be serious first amendinent problems. It does not, and this eliminates a significant set of constitutional criticisms. ${ }^{142}$

every case should expect to articulate the speech values advanced by this medium. But when regulations are questioned as unconstitutional, citing the first amendment interests of cable as the basis, it seems vital to make this connection. Moreover, basing first amendment rulings involving franchising on decisions like Miami Herald Publishing Co. v. Tornillo, 418 U.S. 241 (1974), as the Santa Cruz decision does, short-circuits the balancing analysis usually required in non-content-related cases.

139. See L. TRIBE, AMERICAN CONSTITUTIONAL LAw $791-92$ (2d ed. 1988).

140. 47 U.S.C. $\S 558$ (Supp. III 1985). The Act also permits a franchising authority to bar programming on a leased access channel if, in its judgment, it is "obscene, or is in conflict with community standards in that it is lewd, lascivious, filthy, or indecent or is otherwise unprotected by the Constitution of the United States." Id. \&532(h). This ambiguously drafted provision could prove problematic if "lewd, lascivious, or filthy" is defined to imclude material that is otherwise not obscene or indecent. Indecent programming on cable, which may be limited to certain hours in broadcasting, see FCC v. Pacifica Found., 438 U.S. 726 (1978), is more generally protected if lock boxes are present, Cruz v. Ferre, 755 F.2d 1415 (11th Cir. 1985); $c f$. Jones v. Wilkinson, 800 F.2d 989 (10th Cir. 1986). The Act seens to recognize this by providing that, instead of banning programming under section 532(h), an authority may require that it be provided "subject to conditions," including, assumably, lock boxes.

141. The FCC has adopted content-based cable regulation. The faimess doctrine, requiring operators to afford reasonable opportunity for the discussion of conflicting views on issues of public importance, 47 C.F.R. $\$ 76.209$ (a) (1987), arguably applies to cable, although it has not becn enforced against cable operators since 1974. Faimess Doctrine and Political Cablecasting Requirements, Notice of Proposed Rulemaking, [Current Service] Rad. Reg. 2d (P \& F) 85:115, 85:117 n.3 (1983). In 1983, as part of its general review of the fairness doctrine, the FCC questioned whether authority existed for continued fairness doctrine regulation of cable operators, $i d$., but that proceeding has not been concluded. In light of the FCC's finding that the fairness doctrine is unconstitutional and against public policy in broadcasting, Syracuse Peace Council, 63 Rad. Reg. 2d (P \& F) 541 (1987) (appeal pending), its validity as to cable is in serious question. The Federal Eleetion Campaign Act of 1971, Pub. L. No. 92-225, 86 Stat. 3 (1972), apphed the equal opportunity requirements for political candidates to cable television systems, 47 U.S.C. § 315(a) (1982), codifying a nearly identical FCC rule, 47 C.F.R. $\S 76.205$ (1988) (current version).

142. "And if $I$ have exaggerated, it is only to make clear the dangers that beset us when we lose sight of the First Amendment itself, and march forth in blind pursuit of its "values." " Columbia Broadcasting Sys., Inc. v. Democratic Nat'l Comm., 412 U.S. 94, 145 (1973) (Stewart, J., concurring). Steven Shiffrin has invoked the Caps Lock key to put it well another way: "Genuine progress in free speech theory might well be achieved if commentators talked less about FREEDOM OF SPEECH and more about speech." Shiffrin, supra note 130, at 1212; see also Robinson, Cable Television and the First Amendment, CoMM. \& L., Oct. 1984, at 61 ("There may be first amendinent limits on local regulation, but not every question of regulatory policy sliould be elevated to a constitutional issue merely because it involves a communications medium."). 
What of the Act's grant of authority to enforce franchise provisions that mandate broad categories of programming? This provision could be viewed as content-related interference with the operator's discretion over channels, which is protected to some degree by the first amendment. ${ }^{143}$ Program category requirements, however, generally result from negotiations that ratify what the operator had planned to carry anyway. To the extent that a substantial disagreement nnight arise about such a requirement, a court should probably recognize the requirement's diversity-enhancing aspect, assunning that it is not an irrational stab at diversity. In any case, inclusion of a category leaves the operator with unlimited latitude on how to program it. Thus, this one content-related requirement should not violate the first amendment in principle. ${ }^{144}$

\section{B. Exclusive Franchising Under the Act.}

1. Non-Content-Related Review Generally. The remaining Cable Act regulations, particularly exclusive franchising and access regulations, affect non-content-related aspects of operators or would-be operators. Analyzing such regulations, in which the government does not seek to suppress a message or an idea as such, typically does not involve the fatal scrutiny applied to content-related laws. On this "track two," the Court applies more than a single standard, engaging in an essentially ad hoc balancing of the first amendment values inninged upon by a regulation against the societal interest advanced to justify it. ${ }^{145}$

In balancing the constitutionality of exclusive franchising, many approaches could be taken. Simply observing that franchise regulation under the Act is "content-neutral" short-circuits the analysis, ${ }^{146}$ even though the Court may sometimes use the phrase as a statement of its

143. It could also interfere with market forces: the city could demand that a system carry a program category that attracts a smaller audience than other channels. But demands, say, for a Chinese-language service in a commumity with few Chinese speakers is far-fetehed. On the other hand, the Act does permit cities to obtain and enforce public, governmental and educational access cliannels that are not necessarily market-driven.

144. The problem could conceivably arise under this scenario: An operator is required to provide a Spanish-language channel but, as a behever in an English-only society, feels that being forced to carry such a channel violates his first amendment rights. This situation is unlikely to arise because a requirement for a Spamish-language channel would be absurd where there was no audience for it, and, conversely, market forces would usually lead a cable operator to provide it where a market exists. Should it arise, however, such a requirement could be justified as furthering diversity, favoring the audience's interest in such programming over the operator's desire not to carry it. This is similar to the more likely problem raised by an operator's objections to programming on access cliannels with which it does not agree. See infra notes 205-22 and accompanying text.

145. Stone, Content-Neutral Restrictions, 54 U. CHI. L. REv. 46 (1987).

146. See Clark v. Community for Creative Non-Violence, 468 U.S. 288, 313 (1984) (Marshall, J., dissenting); Redish, supra note 137. For a discussion and partial defeuse of the content-based/content-neutral distinction, see Stone, Content Regulation and the First Amendment, 25 WM. \& MARY 
conclusion. Content-neutral regulations apply evenhandedly on their face, even though they may in fact have a greater impact on some speakers than others. For instance, bans on sound trucks or leaflets, while neutral on their face, can reasonably be seen to affect some types of speakers disproportionately. The touchstone is to determine how severely the restriction affects remaining opportunities for free expression.

Courts, particularly in the cable context, ${ }^{147}$ take on so-called content-neutral problems through the test developed in United States ${ }$. O'Brien, ${ }^{148}$ but the test's predictive value is dubious. At its most helpful, it appears to offer a sensible restatement of traditional balancing, provided that the regulation at issue is in fact content-neutral. A court reviewing content-neutral regulations, particularly of a multiple-activity medium with competing first amendment interests, must be guided by a search for the actual regulation's suppressive effect on opportumities for expression.

2. The Nondecision in Preferred. The Cable Act permits a city to franchise an unlimited number of operators for the same territory. In practice, cities usually grant de facto exclusivity to one operator, in return for which the city may receive franchise fees, universal wiring, ac-

L. REV. 189 (1983); see also Stephan, The First Amendment and Content Discrimination, 68 VA. L. REV. 203 (1982).

147. See, e.g., Quincy Cable TV, Inc. v. FCC, 768 F.2d 1434, 1453-54 (D.C. Cir. 1985) (expressing "some doubt about the appropriateness of shunting the must-carry rules onto the analytical track reserved for other incidental burdens on expression"), cert. denied, 476 U.S. 1169 (1986).

148. 391 U.S. 367 (1968). In O'Brien, the Court was faced with evaluating the protection to be given a mixed speech/conduct situation. It upheld a federal statute prohibiting any person from knowingly destroying a draft card, as apphed to a person who publicly burned his draft cards as a symbolic expression of protest against the draft and the Vietnam War. Under O'Brien, such a regulation is justified if "it is within the constitutional power of tle Government; if it furthers an important or substantial governmental interest; if the governmental interest is unrelated to the suppression of free expression; and if the incidental restriction on alleged First Amendment freedoms is no greater than is essential to the furtherance of that interest." Id. at 377. The Court has lield that this test is equivalent to the analysis that applies to time, place, or inanner restrictions, which requires the presence of a substantial government interest that is unrelated to the suppression of expression. See Community for Creative Non-Violence, 468 U.S. at 298-99 n.8.

If not inet, the third part of $O^{\prime} B r i e n-t$ liat the governmental interest be unrelated to suppression of free expression-triggers strict scrutiny. Where no sucl relation is demonstrated, however, the O'Brien standard is lighlly deferential. It lias never resulted in Supreine Court invalidation of an imcidental restriction on speecl. Stone, supra note 145, at 52 n.23 (reviewing Court applications of O'Brien). This result differs from the approacl taken by the United States Court of Appeals for the District of Columbia Circuit, which has found two FCC rules violative of the first amendment under the O'Brien formulation. See Quincy Cable $T V$, Inc. 768 F.2d at 1454-63 (must-carry rules), cert. denied, 476 U.S. 1169 (1986); Home Box Office, Inc. v. FCC, 567 F.2d 9, 46-51 (D.C. Cir. 1977) (per curiam) (pay TV programming anti-siphoning rules), cert. denied, 434 U.S. 829 (1977). Some evidence that the D.C. Circuit is misapplying the O'Brien test comes in Community for Creative NonViolence, in which the Supreme Court came to the opposite conclusion on application of the fourpart test and sustained the government's action. 468 U.S. at 298. 
cess channels and other benefits. The operator, in turn, seeks benefits froin the city ${ }^{149}$ in order to operate a distribution system that may or may not contain the operator's original expression. ${ }^{150}$

Exclusive licensing has becoine a first amendment battleground for excluded applicants, as manifested in the Court's decision in City of Los Angeles v. Preferred Communications, Inc. ${ }^{151}$ Preferred declined to participate in Los Angeles's competitive franchise auction procedures. ${ }^{152}$ Instead, claiming that sufficient space existed on poles and ducts for a second operator, it sought to lease that space directly from public utilities. The utilities said that a franchise was required before leases could be arranged. Because Preferred had failed to join the auction, the city denied it a franchise. Preferred argued that since it could carry programining different from the auction winner's, it stated a claim for redress under the first amendment.

In a notably brief opinion, the Court held that dismissal of this claim by the district court was inappropriate. Preferred had the right to a trial to test the factual basis on which the city based its pohicy of exclusive franchising. ${ }^{153}$ Recognizing that a cable operator commumicates

149. In any event, the city should not be permitted to use the franchising power to deny use of its police powers based on the proposed speech of the franchise applicant. Cf. Quincy Cable TV, 768 F.2d at 1449 ("No doubt a municipality has some power to control the placement of newspaper vending machines. But any effort to use that power as the basis for dictating what must be placed in such machines would surely be invalid.").

150. In broadcasting terms, it is the equivalent of a protected, exclusive frequency in the electromagnetic spectrum, of no communicative value itself but critical to the broadcasting of a message. In newspaper terms, it compares to the delivery system-door-to-door paper route carriers, the postal service, street vendors, or racks. Some of these, such as broadcast frequencies or paper rack locations, may involve bestowals of benefits for which the public can expect to be compensated.

151. 476 U.S. 488 (1986), aff'g in part 754 F.2d 1396 (9th Cir. 1985). Preferred also claimed violations of federal antitrust laws as well as various state-law violations. The court of appeals affirmed the district court's dismissal of the antitrust claims; the state-law claims were dismissed without prejudice for refiling in state court. 754 F.2d at 1399 n.1.

152. Consistent with the practice of most municipalities, Los Angeles follows a policy of franchising only one applicant to build and operate a cable system, based on competitive bidding. The auction participant in Preferred was required to pay filing fees, provide a detailed proposal of intended operations, demonstrate a sound financial base and business plan, and promise to provide a percentage of future annual gross revenues, a 52-channel system, lcased and public access channels, portable production facilities, and other items. 754 F.2d at 1400-01.

153. There is some confusion as to what some of those issues are. The Court specified that it wished more factual development on the city's claims relating to: (1) the visual blight created by installation and repair of the systems; (2) traffic delays and hazards imposed by the systems; and (3) use that a cable operator makes of public property (a small installation versus 700 miles of cable). 476 U.S. at 492 . Physical scarcity, which secmed to be a central question in the court of appeals decision, 754 F.2d at 1401, 1411, appears to be conceded in the Supreme Court's decision. See 476 U.S. at 492 ("The City [admits] the existence of excess physical capacity on the utility poles, the rights-of-way, and the like ...."). Finally, the city's claim that cable is a natural monopoly, justifying but one franchisee, was recognized as one of the factual issues by the court of appeals. 754 F.2d at 1404 ("The City asserts next that, because cable television is a natural monopoly, economic scar- 
"through original programming or by exercising editorial discretion over which stations or programs to include in its repertoire," the Court concluded "that activities in which [Preferred] allegedly seeks to engage plainly implicate first amendinent interests." 154 But the decision left the standard for judging challenges to exclusive franchising policies wide open. ${ }^{155}$

Acknowledging a first amendment question, however, is different froin deciding whether such a question is serious or frivolous. In Preferred, the Court refused to offer much direction in its short statement, making the decision of hittle value in deciding the constitutionality of exclusive franchising. ${ }^{156}$

3. Cable Franchising as a Public Forum Problem. As an imitial matter, an excluded franchise applicant imight insist that the right to select programs on cable operates as an mdependent first amendment interest. The constitutional basis for a right to build a system, given adequate pole and duct space, is that the claimed use occurs on public property, where speakers-or cable distributors-historically have a right to be.

Under public forum doctrine, the court has divided public property into three categories. ${ }^{157}$ Places that "by long tradition or by government fiat have been devoted to assembly and debate," such as streets and parks, carry the presumption that expressive rights may be exercised there. ${ }^{158}$ A second category, nontraditional public places, may be

city justifies government regulation. We need not decide this issue at this time. [Preferred's] complaint alleges that competition for cable services is economically feasible in the Los Angeles area. As we must accept this allegation as true, we assume that no natural monopoly exists."). The Court read the Ninth Circuit opinion this way, 476 U.S. at 493 , but failed to list it among the factual issues near the opinion's end, $i d$. at 495 .

154. 476 U.S. at 494.

155. The concurring opinion of Justice Blackmun, joined in by Justices Marshall and O'Connor, emphasized that the standard for judging the first amendment challenges to a city's exclusive franclising practice was to be left wide open. Id. at 496 ("Recognizing these considerations ... the Court does not attempt to choose or justify any particular standard."). The Court's decision to duck the questions in the case may be related to the speed of its decision and the case's preliminary procedural posture. Argued April 29, 1986, the decision was issued June 2, 1986. The Brief of the Solicitor General urged the Court to avoid making broad pronouncements about cable's first amendment status in this case: "This constitutional question comes before the Court in an extremely abstract posture." Brief of the United States and the Federal Communications Commission as Amici Curiae Supporting Affirmance 12-13.

156. Nor did the Court use the occasion in City of New York v. FCC, 108 S. Ct. 1637 (1988) (reviewing Act-mandated FCC preemption of state technical standards for cable), to provide guidance about the Act's constitutionality.

157. Robert Post has challenged this division tool, arguing that the more appropriate test is the nature of the government action in question. Post, Between Governance and Management: The History and Theory of the Public Forum, 34 UCLA L. REv. 1713, 1765-84 (1987).

158. Perry Educ. Ass'n v. Perry Local Educators' Ass'n, 460 U.S. 37, 45 (1983). Such places have "inmemorially been held in trust for the use of the public." Hague v. CIO, 307 U.S. 496, 515 
deemed "for use by the public as a place for expressive activity" even though the government need not liave created a forum in the first place. ${ }^{159}$ A third category does not imvolve a forum at all: a nonpublic forum comprises public property that, by tradition or designation, is not for public communication. So long as regulation of nonpublic fornms is not an effort to suppress speech because of the speaker's viewpoint, government regulation barring access is not forbidden. ${ }^{160}$

Whatever the pole and duct space necessary for cable transmission is, it is not a public forum by tradition or designation. ${ }^{161}$ The communicative activity that takes place in a forum has a combined transmission and information function. A speaker speaks on a street corner. A leafleteer passes out tracts in airports, terminals, or city hall lobbies. The ligher scrutiny given to regulations that suppress these activities, even in a content-neutral way, emanates froin the law's presumption that expression in these places must ordmarily be allowed. Courts, rightly, are less concerned with claims of alternatives for silenced speakers.

Space on a pole for a coaxial wire or $m$ an underground duct is not a forum at all, unless the abstraction of "forum" is to include the building blocks of transmission-like paper and ink for primted matter or wood for placards. The problein here differs somewhat froin Members of the City Council v. Taxpayers for Vincent, ${ }^{162}$ in which the Court upheld a municipal ordmance prohibiting posting of any signs on public utility poles. It rejected the arguinent that the poles were public forums by tra-

(1939) (Roberts, J., concurring in part and dissenting in part). Other traditional places for public speech such as state fairgrounds, capitol grounds and public transportation terminals may also fall into this category. Time and place regulations are permissible, but a hard look will be given to their effect on speech.

159. Perry Educ. Ass'n, 460 U.S. at 45 . Here, the analysis focuses inore on providing equal access for all speakers, not necessarily guaranteeing access to the first speaker. These nontraditional forums may include libraries, see Brown v. Louisiana, 383 U.S. 131, 141-43 (1966), theatres, see Southeastern Promotions, Ltd. v. Conrad, 420 U.S. 546, 563 (1975) (Douglas, J., separate opinion), jail environs, see Adderley v. Florida, 385 U.S. 39, 49 (1966) (Douglas, J., dissenting), military bases, compare Flower v. United States, 407 U.S. 197, 198-99 (1972) with Greer v. Spock, 424 U.S. 828, 834-38 (1976), buses, see Lehınan v. City of Shaker Heights, 418 U.S. 298, 310 (1974) (Brennan, J., dissenting), and schools, see Perry Educ. Ass'n, 460 U.S. at 56 (Brennan, J., dissenting).

160. 460 U.S. at 48-49. Access must only be "reasonable; it need not be the most reasonable or the only reasonable limitation." Cornelius v. NAACP Legal Defense \& Educ. Fund, Inc., 473 U.S. 788, 808 (1985) (emphasis in original) (government fund-raising drive literature and procedures deemed nonpublic foruin); Perry Educ. Ass' $n, 460$ U.S. at 46 (school teacher mailboxes); City Council v. Taxpayers for Vincent, 466 U.S. 789, 803-05, 813-15 (1984) (sides of telephone poles).

161. A statute considered in Preferred, CAL. PUB. UTIL. CODE $\S 767$ (b) (West Supp. 1988), dedicates surplus space and excess capacity on public utility support strnctures for use by cable television companies. But this grant does not establish these facilities as a forum; it only gives franchised cable companies a right to negotiate for such space.

162. 466 U.S. 789 (1984). 
dition or designation. ${ }^{163}$ The Vincent Court did not reach the question whether posting signs on poles was a compatible use, ${ }^{164}$ but concluded that the city had properly decided that any postings violated aesthetic standards. ${ }^{165}$

The taxpayers supporting Vincent presented a better case for declaring telephone poles to be forums than do would-be cable operators, because the surface of the pole is a location for stapled placards. It corresponds to forums like bulletm boards at state universities or billboards along roads. It is a place where speech and transmission are jomed. The pole space, at issue in Preferred, is a part of a transmission pathway. ${ }^{166}$ Extending public forum concepts to building blocks of transmission departs from the Court's notions of what a public forum is. ${ }^{167}$ The more apt forum analogy is to say that the channels of a system are a sort of public forum created by a grant of a franchise. But then, through the leased cliannel provisions of the Act or franchise provisions establishing PEG outlets, the government has created access to that "forum" for the expressive activities of excluded operators and others.

4. Does the Cable Act Accommodate the First Amendment Interests of Excluded Operators? Following the "go/no go" conclusions in pubhic fornm cases, once the property to which access is sought is deemed to be a nonfornm, the first amendment concerns of excluded operators can be analytically dispensed with. Absent content-related franchising, the city is relatively free to do as it pleases, were traditional public fornm analysis to decide the matter. However, declaration of a place or space

163. Id. at 814-15. The Ninth Circuit decision in Preferred, in a confusing turnabout, attempted to distinguish Vincent by observing that the stringing or laying of cable was "basically compatible with the nornal use" of poles while plaintiffs in Vincent sought a presumably incompatible place to post signs. Compare Preferred Communications, Inc. v. City of Los Angeles, 754 F.2d 1396, 1408 (9th Cir. 1985) ("We reject the contention that merely because utility poles and conduits are located on or under public streets and rights-of-way, they constitute traditional public forums."), aff'd, 476 U.S. 488 (1986) with $i d$. at 1409 ("Treating the utility structures as a type of public forum places limits on the City's ability to exercise its hicensing power.") and id. ("Moreover, even if Vincent requires the conclusion that the utility poles and conduits do not constitute a public forum for the purpose of cable transmissions ....").

164. Indeed, posting signs on poles generally has no effect on the operation of the power lines strung above. And a casual look at the poles along the strects of any major city reveals that such use, legal or not, regnlarly occurs.

165. 466 U.S. at 807 .

166. It could be argued that Vincent involved total exclusion from a nonforuin, whereas Preferred involves access for one speaker, nainely the chosen franchisee, but not others. Vincent, then, does not justify the discrimination exercised by Los Angeles in providing access to the "forun". The result only occurs if one accepts the view that raw transmission elements are a "forum."

167. Even the space in Pacific Gas \& Electric was not analyzed by the public forum analysis, although access to it was ordered by state law. See Pacific Gas \& Elec. v. Public Utils Comm'n, 475 U.S. 1, 26 n.1 (1986) (Rehnquist, J., dissenting). 
as a nonforum assumes that some alternative method of commumicating exists. For speech or print commumications, there are always street corners or the postal service. To return to the example of the airport bookstore franchise, ${ }^{168}$ an excluded operator can sell books near the airport or even at other locations in the airport terminal. Access to the winning franchisee's shelves is not critical to a message's being received in the forinat desired by the speaker.

For television prograins, similar alternatives do not come to mimd. A video message could be distributed by cassette to willing recipients much like a leaflet, ${ }^{169}$ but with current manufacturing costs, it is an unlikely alternative for nost speakers. And programmers have no right of access to broadcast facilities. ${ }^{170}$ One response to this absence of video alternatives is to observe that the content of a message may be reduced to the written or spoken word. In that forn, traditional public forums could be used. While this inay suffice, it fails to account for the obvious differences between video and printed versions of a message. ${ }^{171}$ And it ignores what has been a constant im cable policy discussions and an operating principle of the Cable Act itself-the large number of channels available in a cable system.

Thus, we should focus on what is lost in free speech terins when one, rather than two, franchises is granted. This analysis can proceed both from the point of view of the would-be second operator as a "speaker" and from the point of view of the would-be audience, deprived of the second operator.

From an operator-as-speaker viewpoint, as we have seen, a franchisee does hittle if any original speaking and considerable amounts of selecting the expression of others for distribution. From the perspective of origination, an excluded operator could nevertheless express itself on cable television by way of access channels, paid or public. The denial of a franchise when there are sufficient opportunities for access does not, then, deny the excluded speaker the ability to say anything it wishes in its own voice by means of cable. Nor does it deny the audience the opportunity to hear those views. The Act's interactivity is most apparent here: its dual creation of access opporturities and the right to grant exclusive

168. See supra text accompanying note 47.

169. In the commercial context, the Soloflex Company, through its print advertisements, offered video cassettes of its patented exercise device in operation. In the political sphere, the United Farm Workers Union advertised free copies of a video tape on use of pesticides by grape growers as part of its information boycott campaign.

170. Columbia Broadcasting Sys., Inc. v. Democratic Nat'1 Comm., 412 U.S. 94, 112-13 (1973).

171. See generally J. McGinniss, The Selling of the President 1968 (1969); M. Mcluhan, Understanding Media: The Extensions of Man (1964); T. SchwarTz, The RESPONSIVE CHORD (1972). 
franchises justifies the effects of required access on cable operators while it mitigates the speech consequences on those excluded.

One might still ask: is the access created sufficient to meet the demand of those excluded? As noted, leased and even public access channels liave not been avidly sought out, so the problem of too many seekers for too few channels remains entirely theoretical. Demial of a franchise does nevertheless prevent the excluded applicant from operating as a channel selector. Here, the criteria that operators use to select prograin channels are relevant. If two systems were to be built, they would offer substantial overlap of the same, most popular program services, with variations at the margin. Under the Act, marginal program services excluded by the winning franchisee may reacl the cable audience through leased or public access. Assuming sufficient channel capacity for sucl excluded services on access, the audience receives essentially the same mix that two services would provide, so long as the losing operator (or the excluded sattehte service directly) seeks access to the system.

In practice, most program services try to negotiate space on a system, rather than invoking leased access riglits. Yet does the first amendment require that an excluded franchisee be permitted to carry excluded services, for reasons other than the benefits to the audience and the program service's own right to express itself? The answer is that, while the speaker has a protected right to speak directly, the interest of the distributor may be less significant. ${ }^{172}$

Insisting on a first amendment right to distribute that which can be directly distributed runs into the common-sense concept of speech. One can argue unfacetiously that a human being speaks only one sentence at a time. The freedom of speech is broader than the spoken word, but the more one distributes programming witlout control over wliat is expressed, the less such activity resembles one's own expression. ${ }^{173}$ A

172. Buckley v. Valeo, 424 U.S. 1 (1976), sustained those parts of the Federal Election Campaign Act of 1971 that limited contributions to a candidate for federal office but invalidated those parts that limited expenditures in support of each candidacy. The opinion einphasized the difference between a candidate herself "speaking" through expenditures and the speech interests of contributors, which were derivative because they were attached to the candidate's speech. When an excluded operator is speaking on an access channel, it is comparable to the expenditure situation. When the operator speaks indirectly only by selecting another's speech, it acts indirectly, as the contributor does in the campaign arena, and limits upon it may become less important.

Also consider Young v. American Mini Theatres, Inc., 427 U.S. 50 (1976), in which the Court appeared to deemphasize the rights of film exhibitors by sustaining a Detroit zoning ordinance prohibiting locating adult book stores, theatres, hquor stores and the like near each other. Since the films at issue could be shown, the fact that a particular exhibitor could not show them did not concern the Court. Id. at 71 n.35. Similarly, the fact that a particular cable operator is demied the right to show a channel is not so intportant, so long as the underlying program service inay reach the audience.

173. Stephen Barnett approaches this slightly differently: 
leased access user needs more than one channel not to offer its own words, but to distribute the words of others. ${ }^{174}$ Those words may be important, but there is no reason why the first amendment requires a nonspeaker to be guaranteed the right to join them simultaneously with another message, so long as the authors of the messages may as easily reach the public on their own. ${ }^{175}$ Once a nonfranchisee obtains one access channel to communicate its message, its first amendment claim becomes more like a deinand for commercial freedom to operate as a product distributor-an eminently reasonable deinand, but not one judged by the stricter scrutiny reserved for speech questions. ${ }^{176}$

Still, it might be claimed that without the intervention of the wouldbe operator, the audience would never know about or receive the excluded service. ${ }^{177}$ The excluded operator can be analogized in this con-

Recognition that the editorial discretion of the cable system consists overwhelmingly of choosing among full-time program supphers-the "primary" speakers-simply suggests the perversity of allowing the cable-system owner, in the name of the First Amendment, to stand astride the cable gateway and prevent those speakers from reaching the public except at his pleasure.

Barnett, Franchising of Cable TV Systems to Get Airing at Supreme Court, NAT'L L.J., Apr. 21, 1986, at 44 n.20. This observation not only supports the status of the access seeker, as Barnett argues. It also tends to reduce the constitutional claim of a nonfranchisee, who would be without particular knowledge or a personal stake in most if not all the programming it would distribute.

174. On the other hand, the court of appeals in Quincy found that limitations on that right under the must-carry rules violated the operator's first amendment rights. See supra note 31 . One conld construct an argnment that the burden found impermissible in Quincy is smaller than the outright denial of a franchise, however conditioned by must-carry rules. This argument, however, mixes the different speech and conduct functions of a cable operator, equating possession of a franchise with the exercise of first amendment expressive rights. What is important in the franchise context is to measure whether the excluded operator possesses alternatives for expression and the effect of the loss of a second franchise on the audience.

175. The situation miglit be different if the voices that the excluded operator wislied to distribute could reach the audience no other way than through a distributor. For example, without some form of independent distribution, recording artists unaffiliated with a major distributor might find it impossible to release records. The same may be trne for others who cannot afford the transaction costs of self-distribution. For cable services, however, national distribution by satellite reduces the transaction cost probleins. For program services, the problem is not distribution but convincing a system to carry it as part of their offering rather than having to consider the access route.

176. Cases upholding first amendment riglits of distributors have arisen when the distributor stands in the shoes of the author whose expression the government wishes to censor. See, eg., Miller v. California, 413 U.S. 15 (1973) (direct mail distributor); Paris Adult Theatre I v. Slaton, 413 U.S. 49 (1973) (film exhibitor); cf. Bantam Books, Inc. v. Sullivan, 372 U.S. 58, 64 n.6 (1963) (book publishers). The same status would be enjoyed by a cable operator or, for that matter, a party operating on an access channel who programs someone else's expression. The first amendment rights protected in these cases relate to the underlying work; tliey do not address the question of the right to engage in the business of distribution.

177. An at least equally likely scenario under multiple franchises is that the competitor will offer a scaled-down menu of programs, perhaps at a price lower than the original franchisee's. The first franchisee, originally assuining that it could serve the whole area and obtain scale discounts from program suppliers, may have originally built a bigger system and provided more program clioice. Under this scenario, this franchisee inight choose to scale back, leaving the public witl price coinpe- 
text to a content promoter who brings audience and content together. ${ }^{178}$ Yet, under leased access, this role is not excluded. An excluded operator could run its own mini-system, leasing as much capacity as needed to carry others who choose not to do it for theinselves. At some poimt that capacity could run out and more leased access capacity would have to be made available, ${ }^{179}$ but that predicament reinains entirely theoretical.

Moreover, access channels, and not the grant of a second franchise, are most likely to lead to the dissemination of program services not selected by an exclusive franchisee. Suppose a franchisee provides MTV. If the system refused to carry a cable network that competes with MTV, that network could offer its programs on a leased access basis directly to subscribers. The network would not depend on the availability of a competing franchisee to be heard. Indeed, if a second franchisee also declined to carry the excluded service, the network-and the goal of diversity embodied in the first amendment-would be no better off. And the network would be inost unlikely to build its own system to disseminate just itself. Thus, in a systein with access, there is some accomınodation of the interests of the excluded speaker and no evidence that it is difficult for the nonfranchisee to express a particular message, on the inedium of choice or otherwise. ${ }^{180}$

Suppose, finally, that a community wanted an exclusive hicensee operating with fewer than thirty-six channels (eliminating federally inan-

tition as to the most popular program services but less overall choice. Greater diversity of programs for the audience, then, is associated with an exclusive licensee. This thinking may explain the expectations cities have when they select a sole operator rather than seeking the alternative benefits of the competitive model.

178. For example, comedian Jackie Mason's Tony-award-winning show, The World According to $\mathrm{Me-essentially} \mathrm{a} \mathrm{repackaging} \mathrm{of} \mathrm{his} \mathrm{mightclub} \mathrm{routines-became} \mathrm{a} \mathrm{Broadway} \mathrm{hit} \mathrm{because} \mathrm{its} \mathrm{pro-}$ ducer, Nick Vanoff, saw its potential as a theatrical piece. Similarly, film and concert producers perform a creative function in tailoring the talent of a writer or performer for a different or broader audience.

179. See 47 U.S.C. § 532(g) (Supp. III 1985) (allowing FCC to promulgate rules "necessary to provide a diversity of information sources" when certain cable capacity is reached).

180. Cf. Arcara v. Cloud Books, Inc., 478 U.S. 697, 704-07 (1986) (upholding a New York statute authorizing closure of an adult bookstore found to be used as a place for prostitution). The majority was satisfied that the statutory closure did not burden the bookseller's rights impermissibly because "respondents remain free to sell the same materials at another location" and in an accompanying footnote rejected the argument that the closure amounted to an inpermissible prior restraint. Id. at 705-06 \& n.2. The decision is factually questionable because, as the dissent points out, zoning laws allegedly prevented respondents from relocating. Id. at 711 (Blackınun, J., dissenting). But the notion of available alternatives is siguificant to the Court's reasoning. In cable, the availability of access to the nonfranchisee is a ineaningful alternative. Further, it is hard to see that the weight given to a speaker's choice of means in the first amendment context, see Baker, Unreasoned Reasonableness: Mandatory Parade Permits and Time, Place, and Manner Regulations, 78 Nw. U.L. Rev. $937,945-49,972-77$ (1983), is especially relevant where all outcomes will lead to expression over cable channels. 
dated commercial access) and no required public access ${ }^{181}$ so as to keep cable subscriber fees low. The foregoing arguments about access and exclusive franchising miglit suggest that exclusive franchising violates the first amendment rights of an excluded applicant. That conclusion, however, may understate the alternatives available to the excluded franchisee, alternatives that go beyond those available by way of traditional public forums. These could include every mediun, from direct mail to billboards to spot or program-lengtli purcliases on radio or television. A court sliould assess these alternatives as a factual inatter ${ }^{182}$ before declaring the franchising scheme unconstitutional.

\section{Access Regulation Under the Act.}

The relative insignificance of the impact of exclusive licensing on speakers or audiences may depend on the provision for access cliannels im the Cable Act. This makes it necessary to consider whether these provisions unduly burden the first amendinent riglits of a franchisee. The answer must depend in part on the effect of access for excluded speakers on diversity of expression. Preliminarily, we need to consider whether the Act's imposition of access channels amounts to mipermissible contentbased regulation of an operator.

1. Noncommercial Access: Government and Educational Channels. As noted earlier, the Cable Act, in addition to creating a catch-all public access category, permits a city to assign cliannels to educational and governmental entities. The operation of access for educational and government uses seems straightforward enough, althouglı some complications are worth noting.

Cable operators must decide which educational authority im the community will schedule the educational clrannel. The same is true for the government cliannel. Cliannel administration does not pose a content-related problem, but assigning cliannels to educational and governmental users is arguably a content-based decision, simce the categories limit who may use them. "Public", in contrast, theoretically excludes no one. Classification becomes more of a problem if a city council, as franchising autliority, asssigns the governinent clrannel to itself in order to

181. This hypothetical is quite theoretical but is presented to raise the question, answered in the negative, of whether access channels are the quid pro quo for exclusive licensing.

182. Had the Court in Preferred focused on this question, it would have come closer to assessing the effects on freedom of expression imposed by the exclusive licensing scheme. Los Angeles had requested that any applicant provide both public, educational and governmental and leased access. Brief for Petitioners at 5, City of Los Angeles v. Preferred Communications, Inc., 476 U.S. 488 (1986) (No, 85-390) (requesting proposals for a 52-channel system). 
feature those in office. ${ }^{183}$

However, the labels "government" and "educational" are not viewpoint-specific. ${ }^{184}$ More importantly, access regulations in general, and these regulations in particular, do not suppress views. ${ }^{185}$ They enhance the speech opportunities of those identified by the categories, without diminishing those of any other speaker. ${ }^{186}$ And since anyone may address the audience of educational and government channels by using pubhic access, the perceived favoritism bestowed on the two channel groups can be redressed on the third. ${ }^{187}$

Media regulation that is diversity-enhancing can nevertheless further the first amendment, even if it poses some limit on the press. In Federal Communications Commission v. National Citizens Committee for Broadcasting, ${ }^{188}$ the Court upheld the constitutionality of an FCC rule barring common ownership of a radio or TV station and a newspaper in

183. Creation of these channels resembles the right that Congress created for its members and others in 47 U.S.C. $\$ 312(a)(7)$ (1982) (providing reasonable access for candidates for federal office). The Court in CBS Inc. v. FCC, 453 U.S. 367 (1981), sustained the FCC's application of the statute in the presidential election context as "an effort by Congress to assure that an important resourcethe airwaves-will be used in the public interest." Id. at 397.

184. Seemingly content-neutral regulation may nevertheless have a greater impact on some speakers than others. Sound trucks have long been the medium of choice of poorer fringe groups. See Kovacs v. Cooper, 336 U.S. 77 (1949) (upholding ordinance banning use of sound trucks). Justice Black dissented in Kovacs, noting that "[T]here are many people who have ideas they wish to disseiminate but who do not have enough money to own or control publishing plants, newspapers, radios, moving picture studios, or chains of show places." Id. at 102. Laws regulating the stuffing of school teachers' mailboxes and the affixing of sigus to telephone poles have been sustained although they can be seen as affecting some speakers more than others. See Perry Educ. Ass'n v. Perry Local Educators' Ass'n, 460 U.S. 37 (1983) (teacher mailboxes); City Council v. Taxpayers for Vincent, 466 U.S. 789, 817 (1984) (utility poles). Also consider Chicago Cable Communications v. Chicago Cable Comm'n, 678 F. Supp. 734 (N.D. Ill. 1988), which upheld fines against an operator for failing to direct its local origination programming toward the commumity of hicense. The court held that enforcement of a localism requirement, short of requiring that particular events be covered, violated neither the first ainendment nor the Cable Act. Id. at 744-47. Requireinents for government or educational channels would seem no more intrusive than requiring an origination channel that perforce focused primarily on the local area.

185. Cable access differs from the situation posed in Chicago Police Dep't v. Mosley, 408 U.S. 92 (1972), which imvalidated an ordinance banning picketing near school during certain hours except when a a school is involved in a labor dispute. The Court was concerned not just with viewpoint discrimination but with the ordinance's ban on a particular subject matter, in that ease, high school quotas as discussed on Mosley's placards. Here, no particular subject is singled out for inclusion or exclusion. The categories refer to two critical functions of a society: governance and education. Moreover, a speaker who does not fit into those categories can still speak on public access.

186. Classifications are common in FCC licensing. For example, certain microwave licenses may be issued only to aceredited educational institutions. See D. BRENNER \& M. PRICE, supra note 9, § 16.02 (discussing the Instructional Television Fixed Service).

187. Access on a government channel may be more valuable, however, because of the official context in which speech appears. By contrast, public areas, which can involve a broad array of speech, including the bizarre, might be a less suceessful context in which to appear.

188. 436 U.S. 775 (1978). 
the same community. The Court rejected the claim that this rule violated the co-owner's first amendment rights. The rule was not contentbased, and its purpose and effect was to promote free speech. ${ }^{189}$ Access channel requirements, too, serve a diversity-enhancing goal, as Congress determined, 190 and are not based on the views of the operator.

For local governments, an access channel is a way to mamtain communication with the public, a part of the political process long recognized in the form of newsletters. Such chaimels encourage awareness of civic matters, by opening city councils to public view, for example, and cannot be directly used by the operator to favor a particular poitical candidate. ${ }^{191}$ The operator does not program the charmel, and the Act relieves the operator fronı legal responsibility for what is broadcast. Government and educational channels represent low-cost ${ }^{192}$ networks for cities, negotiated by then as part of a franchise package. Whether they are wasteful expenditures that drive up cable subscriber rates without a substantial public benefit (a complaimt often raised by cable operators about all forms of access) is a problem separate from whether requiring such channels violates the first anendment in primciple. ${ }^{193}$

189. Id. at 800-01 (distinguishing Speiser v. Randall, 357 U.S. 513 (1958) (striking loyalty oath requirement for veterans seeking property tax exemption); Elrod v. Burns, 427 U.S. 347 (1976) (overturning einployee discharges based on pohitical affiliation)).

190. The House Report accompanying the leased access provisions of the Cable Act noted that while cable operators may provide a diversity of program services, they "do not necessarily have the incentive to provide a diversity of progrannining sources, especially when a particular program supplier's offering provides programining which represents a social or political viewpoint that a cable operator does not wish to disseminate." H.R. REP. No. 934, supra note 81, at 47, reprinted in 1984 U.S. CODE CONG. \& ADMIN. NEwS at 4685. Note also that the Court's review of access requirements in FCC v. Midwest Video Corp., 440 U.S. 689 (1970) speeifically withheld judgment on the first ainendment clain. Id. at 709 n.19; see Cable Television Report \& Order, 36 F.C.C.2d 143, 191 (1972) (describing noncommercial access as "a practical opportunity to participate in community dialogue through a mass medium"); see also Berkshire Cablevision, Inc. v. Burke, 571 F. Supp. 976, 987-88 (D.R.I. 1983) (upholding state agency's mandatory access requirements), vacated as moot, 773 F.2d 382 (1st Cir. 1985).

191. Not that politicians are above asking. At a cable awards cereniony attended by the author, the guest speaker, the mayor of one of the local franchising authorities, announced that she wished the local operator to provide a "Meet the Mayor" program on their service. Donna Smith, Mayor, Pomona, Cal., First Annual Awards Dinner, Southern California Cable Association (Aug. 1987). At least theoretically, refusal to provide this progran could not be used in a renewal proceeding against the operator.

192. The city forgoes some revenue that would come from the franchise fee for costs attributable to PEG channels. See 47 U.S.C. $\$ 542(\mathrm{~g})(2)(B)-(C)$ (Supp. III 1985).

193. This issue arises under the modified contracting approach rccommended by Richard Posner. See R. POSNER, ECONOMIC ANALySIS OF LAw 361-62 (3d ed. 1986). The city, acting as agent for the residents, could solicit bids, setting as its goal the best possible contract for the subscribers. This differs from the arrangement described by Judge Posner as one "to extract concessions from the franchisee as the price of permitting it to charge a monopoly price." Id. at 362. 
2. Access Channels Generally. Public access may be viewed as access leased at less than the market price. Given the power of the operator to determine what is a reasonable price for leasing a cliannel, ${ }^{194}$ it is probably easier for a speaker to appear on public access, assuming that a franchise provides for it.

Noncommercial and commercial public access channels generally call for similar first amendment analysis. ${ }^{195}$ Even more than educational or governmental access requireinents, public access requirements are content-neutral: they are not triggered by the operator's own speecl, nor are they based on the speech content of the person seeking their use. 196

Access cliannels raise two potential first amendinent problems. First, they may take up too many cliannels, imposing more than an incidental burden on the operator's speech. Second, they may lead to an unacceptable association of the cable operator's expression with that of the access seeker.

a. Number of channels claimed by access. Access cliannel. requirements deny an operator the use of cliannels for which it would otherwise select program services. Apart from whether that cliannel selection process slould be characterized as editorial, overall cliaunel carriage requirements can be an unreasonable burden under the first ameudment. The United States Court of Appeals for the District of Columbia Circuit, in Quincy Cable TV, Inc. v. Federal Communications Commission, 197 invalidated the original must-carry rules in part because those rules led operators to dedicate too inany channels to local signals, regardless of viewer or operator clioice.

The reduction in cliannel capacity due to required access, lowever, does not usually approach the degree of control involuntarily ceded under the former must-carry rules. The Cable Act does not specify the number of PEG cliannels to be used. The operator is free to negotiate the extent of its noncommercial access commitinent. And the Act does

194. 47 U.S.C. § 532(c)(1) (Supp. III 1985).

195. One difference between the two is that wealthy individuals could dominate leased public access speech because they could afford more than others. This is similar to the problem raised by the Court in Columbia Broadcasting System, Inc. v. Democratic Nat'1 Comm., 412 U.S. 94, 123 (1973), which upheld the FCC's denial of a right of paid access in broadcasting, in part because of the disproportionate access that affuent speakers could have. In that case, however, the point was raised to defeat a clained constitutional right, not to create one. Further, broadcast spot access and cable channel or even program access are not equivalent. Moreover, leased access can be countered by free access, a situation the Court was unwilling to impose on broadcasting. Indeed, the Court's opinion, taking note of the cable industry at an early stage in its developinent, adverts to "increased opportunities for the discussion of public issues" on public access. Id. at 131.

196. See Barnett, supra note 173 , at 42 , col. 3,43 , col. 1 .

197. 768 F.2d 1434, 1460-61 (D.C. Cir. 1985), cert denied, 476 U.S. 1169 (1986). 
not bind operators to dedicate cable channels in perpetuity in the face of insufficient access deinand. To the contrary, the franchising authority must establish rules to allow the operator to reclaim access channels. ${ }^{198}$

As to leased access, the Act imposes no such requirements on systems of less than thirty-six activated charmels. Even for systems of 100 channels or more, the requirement does not exceed fifteen percent of channels. ${ }^{199}$ And until a written lease is obtamed, operators can ignore leased access requirements. ${ }^{200}$ In practice, many systems with thirty-six channel-plus systems do not set aside leased access chaimels until they are demanded. Thus, unlike the inflexible rules armulled in Quincy, the market of speakers creates a demand for such charmels.

Even so, access obligations could result in exclusion of services that an operator wants to carry and subscribers want to see. There is no complete answer to this objection; however, access channels presumably appeal to some viewers. And cities are free to release operators from all unpaid access obligations in response to subscriber reaction or to exclude them entirely if they turn out to be undesirable. Further, evidence indicates that having ballooning numbers of cable program services may not appeal to viewers. Demand drops off sharply after a subscriber's four or five favorite satellite signals are on a system. ${ }^{201}$ Access channels are not necessarily any less desirable to some viewers than the operator's lastselected choice. Compare cable service to the Sunday paper. Once a reader has plucked out the four or five sections of most interest, the rest of the paper may have hittle value. For some readers, "leased access" in the form of advertising circulars or educational catalognes may occupy the same importance as less-favored sections. So too, for cable. ${ }^{202}$

Finally, cities negotiate the required number of chaimels in the system as part of a franchise, regardless of whether access is required. The burden of access must be viewed in relation to this agreed-upon number

198. 47 U.S.C. $\$ 531(d)(1)$ (Supp. III 1985).

199. See id. $\S 532(\mathrm{~b})(1)(\mathrm{B})$-(C). The Act contemplates that the FCC will reexamine these requirements when 70 percent of U.S. households receive 36 or more channels. Id. §532(g). New rules would have to be reviewed as to their impact on the speech opportunities for the franchisee.

200. Id. §532(b)(4).

201. A study commissioned for the National Cable Television Association found that $80 \%$ of a subscriber's viewing is accounted for by a system's retransmitted broadcast signals plus an additional five or six cable channels. Which half-dozen cable services are desired will vary by subscriber. Browne, BORTZ \& CoDdington, The IMPACT Of COMPETITIVE Distribution TechNologies on CABLE TELEvision (1982). Thus, a low-ranked cable service may be no more desirable than an access channel for a particular viewer.

202. Indeed, some papers tout the carriage of commercial "access customers"-cents-off manufacturers' coupon distributors-as a reason to buy the paper. Narrowcast aceess programs, such as religious or adult fare, may play a similar role in cable. 
of channels. ${ }^{203}$ A requirement that places too high a burden on channel discretion, as the FCC's original must-carry rules did, may violate the first amendment. But at some poimt the inpact of access requirements on channel discretion attenuates to where it cannot be said to violate the operator's rights of expression. 204

\section{b. Access channels as a private forum problem. A second objec-} tion to access requirements is that, however many channels are taken up, their content always burdens a cable operator's speech. Even though the editorial viewpoints of the operator and the access user are not consciously joined, a form of forced association results. A system may be required to carry extremist political viewpoints ${ }^{205}$ or, as in the case of New York City systems, sexually exphicit programs. The operator may complam that viewers, who do not nnderstand that the operator's discretion over such channels has been stripped away by the Act, may disconnect froin the system, preferring not to subscribe if it risks bringing offensive material into the home. ${ }^{206} \mathrm{~A}$ more pertinent objection for first amendment purposes is that the operator is associated with expression not of its choosing; it should not be required to carry messages that it would not otherwise select.

This objection could also be phrased in terms of public forum doctrine: rights of access under the Cable Act create a public forum on the operator's property without the operator's consent. ${ }^{207}$ As noted earher,

203. Cable systems can, of course, add channels to meet access demands. See Nadel, Editorial Freedom: Editors, Retailers, and Access to the Mass Media, 9 COMM/ENT L.J. 213, 238 (1987). Adding channel capacity solely to sustain access at the city's behest, however, is a more costiy burden than initial channel requirements.

204. Two district courts that examined this question of degree sustained access. In Erie Telecommunications, Inc. v. City of Erie, 659 F. Supp. 580, 600-01 (W.D. Pa. 1987), subsequent orders aff'd, 853 F.2d 1084 (3d Cir. 1988), 13 access channels in a minimum 84-channel system were deemed to "produce only a minimal intrusion" on the cable system's exercise of first amendment rights. And in Berkshire Cablevision v. Burke, 571 F. Supp. 976, 979 (D.R.I. 1983), vacated as moot, 773 F.2d 382 (1st Cir. 1985), the reservation of seven of 50 or more channels was found to be no more than was essential to further the government's purpose in creating an access right. Id. at 988; cf. Group W Cable, Inc. v. City of Santa Cruz, 669 F. Supp. 954, 967-69 (N.D. Cal. 1987) (finding franchise access requirements and exclusive franchise grants unconstitutional). But see Century Fed., Inc. v. City of Palo Alto, 63 Rad. Reg. 2d (P \& F) 1736 (N.D. Cal. 1987), appeal dismissed, 108 S. Ct. 1002 (1988).

205. For example, a Kansas City system was asked for program time and training to produce a local show featuring a white supremacy group. This led the system to switch the channel from access to local-origination. Tajima, Showdown in Kansas City: KKK vs. American Cablevision, INDEPENDENT (Film and Video Monthly), Aug.-Sept. 1988, at 4; see Variety, Feb. 3, 1988, at 1, col. 1.

206. Of course, lewd programs may draw a large audience for the operator, one that the operator might like but not take credit for. B. SchMIDT, FreEdOM OF THE PREss vs. PuBLIC ACCESS 213 (1976).

207. This issue is separate from the economic burden imposed by noncommercial access requirements. Leased access requirements do not pose quite the same burden, as the operator may insist 
the public forum doctrine is used to characterize public property to determine whether an individual has a right of expression there. As to access cliannels, the property involved is private. The operator's claim is that access creates an impermissible private forum. Access rights to private property cannot be dogmatically decided, however, based on a single "public/private" distinction ${ }^{208}$ like the one that applies when the owner is deemed to act in placc of the state, ${ }^{209}$ and in some broadcasting contexts as well. ${ }^{210}$

This protest calls to mind two forum-type cases, Pacific Gas \& Electric Co. v. Public Utilities Commission ${ }^{211}(P G \& E)$ and Miami Herald Publishing Co. v. Tornillo. ${ }^{212}$ In $P G \& E$, the Court found that California violated the first amendment rights of a utility when a public service commissioner required the utility to mclude an opposition group's leaflet in "the extra space" of its monthly billing envelope, four tines a year im addition to, or in lieu of, the company's newsletter. The plurality decision concluded that an access right could deter the utility from addressing some issues because its cominents could trigger a duty to msert responses. Alternatively, the plurality decided, forced carriage of the opposition's newsletter might require the utility to address issues raised in

that the access user pay a price that "will not adversely affect the operation, financial condition, or market development of the cable system." 47 U.S.C. § 532(c)(1) (Supp. III 1985).

208. See Fiss, supra note 135, at 1414. In a divided decision, the Court held that private shopping centers lack the characteristics of a public forum, and so the first amendment does not apply to them. Hudgens v. NLRB, 424 U.S. 507, 520-21 (1976). On the other hand, in PruneYard Slopping Center v. Robins, 447 U.S. 74, 80-88 (1980), the Court held that the California Supreme Court could interpret a state constitution to guarantee access to a privately owned sliopping center for signature gathering without violating the owner's constitutional rights. The Court rejected the owners' claim that their first annendment rights were infringed by the forced association with the signature gathering. Id. at 85-88. As the Court later noted, what was "[n]otably absent from PruneYard was any concern that access to this area might affect the shopping center owner's exercise of his own right to speak: the owner did not even allege that he objected to the content of the pamphlets; nor was the access right content-based." Pacific Gas \& Elec. Co. v. Public Utils. Comm'n, 475 U.S. 1, 12 (1986).

209. State action is found under a number of thcories. These include the private party conducting a public function, see, e.g., Marsh v. Alabama, 326 U.S. 501, 509 (1946), state involvement with the private activity, see, e.g., Burton v. Wilmington Parking Auth., 365 U.S. 715, 725 (1961), Shelley v. Kraemer, 334 U.S. 1, 20 (1948), and state authorization or encouragement of private activity, see, e.g., Reitman v. Mulkey, 387 U.S. 369 (1967). The failure of state action claims in private forum cases suggests that these precedents are narrow, particularly where racial discrimination is not at issue.

210. The theory is based on a broadcaster's status as trustee, holding a license and exercising first annendment rights in a limited fashion, in confornity with viewer and listener needs. Red Lion Broadcasting Co. v. FCC, 395 U.S. 367, 389 (1969). These broadcast holdings have not been denoininated as "forum" cases, although the issues are similar. But see Pacific Gas \& Elec. Co., 475 U.S. at 26-27 n.1 (Rehnquist, J., dissenting) (citing Democratic Nat'l Comm. and Red Lion Broadcasting Co. in the forum context).

211. 475 U.S. 1 (1986).

212. 418 U,S. 241 (1974). 
it. It struck down the regulation also because it forced the utility to associate with messages with which it disagreed. ${ }^{213}$

Tornillo involved a challenge to a Florida newspaper right-of-reply statute. The statute provided that a newspaper that attacked a candidate's character or record could be required to print the candidate's reply in equal space and prominence. Tornillo is often cited for rejecting the argument that the Miami Herald's "natural monopoly" in the market could give rise to required access to its editorial pages. ${ }^{214}$ As significant as that point may or may not be, ${ }^{215}$ the case can be read, as it was in $P G \& E$, as condemning access requirements because they discouraged the paper from editorializing. If the paper expressed an opinion, the regulation would force it to let other speakers with whom it disagreed use its facilities. ${ }^{216}$

Cable access does not operate like the schemes invalidated in Tornillo and $P G \& E$. In those cases, the Court thought that the editorial voice of the newspaper and the utility company would be influenced by the access right of an opponent. In cable, the access user is not an opponent, because the user's speech rarely relates to something carried consciously by the operator. Other than adding new ideas-offensive, insightful or tedious-the access user does not influence an operator's agenda. In any case, access rights are not triggered by the operator's decision whether to address an issue. Access is achieved independently of the operator's message. Conversely, access channel use does not force a cable operator to tailor its speech to a user's agenda or to speak when it prefers to remain silent.

213. 475 U.S. at 5-6, 10-15. This view followed from Wooley v. Maynard, 430 U.S. 705, 715 (1977), in which the Court held that New Hampshire could not require citizens to display the state motto, "Live Free or Die," on their hicense plates-an "ideological message" with which some citizens disagreed.

214. See, e.g., Preferred Communications, Inc. v. City of Los Angeles, 754 F.2d 1396, 1404-05 (9th Cir. 1985), aff'd, 476 U.S. 488 (1986); Midwest Video Corp. v. FCC, 571 F.2d 1025, 1056 (8th Cir. 1978); Home Box Office, Inc. v. FCC, 567 F.2d 9, 46 (D.C. Cir.) (per curiam), cert. denied, 434 U.S. 829 (1977); Group W Cable, Inc. v. City of Santa Cruz, 669 F. Supp. 954, 965 (N.D. Cal. 1987).

215. The Court, correctly, did not find that the Miami Herald possessed a natural monopoly in the newspaper market in the metropohtan Miami area at the time of Tornillo's suit. In 1972 Miami had two English dailies (the Herald and the News), one Spanish daily, 15 weeklies, and one biweekly. AYER DIRECTORY OF PUBL1CATIONS 235-36 (1972). In addition, there were other dailies published in South Florida as well as papers like The New York Times and the Pittsburgh Courier, a blackoriented paper, that also circulated in Miami at that time.

216. The statute also intruded into the paper's editorial judgments by forcing it to "tailor its speech to an opponent's agenda, and to respond to candidates' arguments where the newspaper might prefer to be silent." That is, access would upset the newspaper's right not to speak. $P G \& E$, 475 U.S. at 10. A similar argument is made in Group W Cable, Inc. v. City of Santa Cruz, 669 F. Supp. at 969. 
By tradition, access channels are not identified as produced by the operator. They are well-known for their potluck character, with anyone allowed to contribute. This situation produces forced association only in that the same operator is involved; access channel speakers are not perceived as having the carrier's imprimatur. They are like "junk" mail that is carried by the U.S. Postal Service or distributed by landlords, but surely not produced by them. ${ }^{217}$ And the larger truth is that many viewpoints expressed on a cable system as part of the operator's programming can stir resentment. Depictions of violence or sex on a movie channel or a controversial interview on a news channel nnay cause a subscriber to disapprove. To single out cable access channels on the basis of their potential offensiveness is arbitrary.

Cable access also differs from access to broadcasters. ${ }^{218}$ Broadcast access means access to an unreclaimable portion of the finite time available for generatimg revenues. The broadcaster has amassed an audience for its own purpose. The aceess seeker wants to expose its message to an audience that has been drawn to the broadcaster's programs but that

217. In the postal context, the receiver's interest, not the carrier's, in avoiding offensive inaterial is protected. Rowan v. Post Office Dep't, 397 U.S. 728 (1970). And like common carriers licensed by the FCC or broadcasters fulfilling duties under section 315, see Farmers Educ. \& Coop. Union v. WDAY, Inc., 360 U.S. 525 (1959), a cable operator is immune from liability for statements made on access channels, 47 U.S.C. $\$ 558$ (Supp. III 1985).

218. The Court has recognized some access to broadcast signals as constitutional. In Red Lion Broadcasting Co. v. FCC, 395 U.S. 367 (1969), the Court sustained FCC rules giving individuals personally attacked on the air a right of access to allow thein to reply, rules that were part of the faimess doctrine. In Columbia Broadcasting Sys., Inc. v. Democratic Nat'l Comm., 412 U.S. 94 (1973), the Court sustained the FCC's denial of access for paid editorial advertisenents. It held that the FCC could allow one of its licensees to maintain a flat ban on paid public issue-oriented announcements without violating the first amendment rights of the excluded speaker. And in CBS Inc. v. FCC, 453 U.S. 367 (1981), the Court sustained the FCC's interpretation of a federal statute requiring broadeasters to allow candidates for federal office "reasonable access" to purcliase air time. It is hard to conclude much about cable froin these decisions. Not only do they lack a convincing rationale for broadcast regnlation generally, see FCC v. League of Women Voters, 468 U.S. 364, 376 n.11 (1984); Telecommunications Research \& Action Center v. FCC, 801 F.2d 501, 508-09 (D.C. Cir. 1986), but they enpliasize the reasonableness of the FCC's judgment rather than stating general pronouncements about what is permitted under the first amendment. First ameudment claims against the FCC's authority are not accorded great attention. In the first case, NBC v. United States, 319 U.S. 190, 226-27 (1943), the inatter was taken up nearly as an afterthought. In Red Lion in 1969, Democratic National Committee in 1973, and $C B S$ in 1981, the Court sustained the first amendment call by the agency as within its administrative discretion. This judicial bashfulness in favor of deference may also place limits on the constitutional analysis that the Court conducts. In each of these cases, the momentum was already established for finding the agency's decision lawful. First amendment analysis occurred at the end of the opmion, and, as in the $1943 \mathrm{NBC}$ and $1981 \mathrm{CBS}$ cases, took a dismissive tone. Given over 50 years of FCC authority over broadcasting, with no substantial change of the FCC's charter, it is not surprising that the Court has cliosen to deal with the administrative review questions first, with less attention to the constitutional questions. This approach reflects the Court's tendency to defer to the legislative branch where reasonable minds could differ on content-neutral matters. 
may not be imterested in the access message. ${ }^{219}$ In cable, there is no similar "piggybacking" with respect to audience. 220 Access users do not intrude on the operator's speech on an originating channel. Viewers watch access channels not because of anything the operator programs, but because of what access users say. This separation diminishes the effect of access channels on the editorial imdependence of the operator.

Finally, as noted earher, access requirements can be viewed as a permissible condition of a franchising process in which not all who wish to operate a cable system may do so. Exclusive licensing may be permitted under the first amendment because access can ensure the availability of cable outlets for those excluded.221 Unlike broadcasting or newspapers, cable entry usually lias been limited to one operator. Access is an acceptable diversifying principle that ameliorates this exclusivity. ${ }^{222}$

\section{Exclusive Franchising, the Cable Act and the QUESTION OF DEFERENCE}

The foregoing analysis lias urged that any first amendinent attack on the 1984 Cable Act based on its allowance for exclusive hicensing fails. In the arena of ad loc balancing in which licensing questions are to be decided, what einerges is a muinicipality's relatively straightforward, though by no ineans overwhelming, interests in deciding low to exploit its powers to declare eminent domain and grant nontransient uses of its streets. As noted earhier, the other interests sometinnes asserted in these

\footnotetext{
219. Martin Mayer criticizes the right of access:

There is something bittersweet funny about the sight of all these groups of ardent young lawyers and graduate students and junior executives at foundations, none of whom can write a song anyone would sing or a book anyone would read or a play anyone would act, none of whom holds a position which gives his thought significance in the lives of others or could gather twenty-five people to hear him speak at a meeting-"deinanding" access to the great audience of an entertainment inediun.

M. MAYER, ABout TELEVISION 388 (1972).

220. See B. ScHMIDT, supra note 206 , at 212-13.

221. The cities of Palo Alto and Meulo Park, amici in the Preferred case, argued that the access requirements provided unsuccessful franchise applicants with the opportunity to disseminate their inessages, a position with which this article is in mucl agreement. The court of appeals rejected the argument, comparing the access opportumities provided by the leased access statute to "[a] law allowing frec expression in public parks only for a few minutes at 6 a.m." $754 \mathrm{~F} .2 \mathrm{~d}$ at 1410 . With due respect, the court draws a false comparison. There are 24-hour rights to leased access channels, not merely late at might. Further, the first amendment does not guarantee a willing audience but rather an opportunity to be heard. See supra note 213 and accompanying text.

222. This justification for access channels lessens where there is sustained competition among two or inore cable systems. However, long-term, face-to-face competition is a rarity, even where permitted by the franchising authority. See supra note 78. Noncominercial access could be justified as a diversity-enhancing mechanism, so long as the cable operator could assigu their costs against fees owed to the franchising authority. Similarly, requirements for leased access may be permitted so long as the cable operator could charge the lessee a reasonable price, as provided for in 47 U.S.C. $\S 532$ (c) (Supp. III 1985).
} 
cases, such as avoidance of bliglit and traffic delays, or the inevitability of cable as a natural inonopoly, are difficult to prove. ${ }^{223}$ Findings against a city on these issues may simply mask soine objection to the way a city issued its exclusive franclise grant.224 Findings in the city's favor inay reflect the view that the would-be operator is engaged in a form of greenmail with an existing or would-be operator. ${ }^{225}$ Furtlier, some cities do prefer to allow competing franchising, weakening the argument that exclusive grants are inevitably necessary or desirable.

The relatively weak inunicipal interest confronts an even feebler first amendment claim inade by excluded operators. Given an access scheine that permits the unfranchised to speak over cable and permits audiences to hear them, the only first amendment harm done to the excluded operator is the effect on it as a program selector. Here, however, there is likely to be substantial overlap annong the program offerings of any two operators, and opportunities exist on leased access channels for excluded services to attempt to reach the audience, either directly or by using the excluded operator as imterinediary.

In ad hoc, "track two" balancing, however, it is quite possible that a view of these matters could lead to greater recognition of tlie first amendinent impingement to the excluded speaker than is urged here. For mstance, access channels may not be sufficiently plentiful to accommodate all speakers or all of the channels that an excluded operator would choose to operate. Operating on access channels may be viewed as insufficient, given the reputation of public access and the mability of a public access user to control which channel it appears on or adjacent to. Leased access might be unreasonably withheld or commercially impractical because it would be difficult to find a way to charge custoiners. Or one inay find the risk of undetectable viewpoint discrimination too high to sustain even the slightest impingement on excluded access seekers.

223. See supra notes $76-80$ and accompanying text.

224. This may be the case in two of the three reported cases in which a finding on natural monopoly was reached. In Pacific West Cable Co. v. City of Sacramento, 672 F. Supp. 1322, 1349 (E.D. Cal. 1987), the jury was asked to decide whether a natural monopoly existed for cable TV in the Sacramento market. It found negatively, but it also found that the grant involved questions of political contributions that influenced the franchise award. See supra note 73. And in Central Telecommunications, Inc. v. TCI Cablevision, Inc., 610 F. Supp. 891 (W.D. Mo. 1985), aff'd, 800 F.2d 711 (8th Cir. 1986), cert. denied, $107 \mathrm{~S}$. Ct. 1358 (1987), the jury found that a natnral monopoly existed. But anticompetitive conduct by the incumbent franchisee, who had argued in its defense that no monopoly existed, led to a $\$ 32.4$ million judgment against it. This finding may have influenced the factinders on the monopoly question.

225. In Nor-West Communications v. City of St. Paul, No. 3-83 Civ. 1228 (D. Minn. 1988), the third natural monopoly verdict, the jury found that the would-be franchise applicant was not ready, willing and financially able to build a competing cable system. See Jaffe, Jury Determines Nor-West Not Able to Wire St. Paul, Multichalsnel News, June 13, 1988, at 5. 
Given that the first amendment concerns here may be close calls, should courts take into account the conclusions reached by Congress about franchising and access? The high school civics solution is no: as Marbury v. Madison ${ }^{226}$ teaches, the judiciary is to make an independent examination of constitutional matters; first amendment rights, moreover, are so crucial that deference should play no role. This view is seconded by academics, who abhor the thought that an independent judiciary would defer to the legislature in first amendment matters. There are good $^{227}$ and not-so-good reasons for this distaste. ${ }^{228}$

Despite that monochromatic view, the Court in fact has deferred to Congress's judgments in first amendment areas, particularly where media have been involved. ${ }^{229}$ Consider, for example, the Court's approach in Columbia Broadcasting System, Inc. v. Democratic National Committee $(D N C) .{ }^{230}$ The FCC had rejected the request of two groups that claimed a right under both the first amendment and the Communications Act to buy time to solicit funds and to comment on public issues. The Court upheld the FCC, noting that in evaluating a first amendment claim, it "inust afford great weiglit to the decisions of Congress and the experience of the Commission."231 It continued in a passage worth quoting at length:

The judgment of the Legislative Branch cannot be ignored or undervalued simply because one segment of the broadcast constituency casts its claims under the umbrella of the First Amendment. That is not to say we 'defer' to the judgment of the Congress and the Commission on a constitutional question, or that we would hesitate to invoke the Constitution should we determine that the Commission has not fulfilled its task with appropriate sensitivity to the interests in free expression. The point is, rather, that when we face a complex problein with many hard questions and few easy answers, we do well to pay careful attention to how the other branches of government have addressed the same problem. ${ }^{232}$

In some respects, broadcasting is a poor starting place to decide

226. 5 U.S. (1 Cranch) 137 (1803).

227. For example, consider the Court's willingness, typified by Justice Frankfurter's concurring opinion in Dennis v. United States, 341 U.S. 494 (1951), to defer in hard political cases. See Linde, "Clear and Present Danger" Reexamined: Dissonance in the Brandenburg Concerto, 22 Stan. L. REV. 1163 (1970).

228. Academics inay overstate the importance of caselaw as the only factor to be considered in the development of constitutional law. See Leedes, The Supreme Court Mess, 57 TEx. L. REv. 1361, 1365-66 (1979); Tushnet, Truth, Justice, and the American Way: An Interpretation of Public Law Scholarship in the Seventies, 57 TEx. L. REv. 1307, 1337-38 (1979).

229. See Cox, The Role of Congress in Constitutional Determinations, 40 CiNN. L. REV. 199, 229-30 (1971); Monaghan, Constitutional Fact Review, 85 Colum. L. REv. 229 (1985).

230. 412 U.S. 94 (1973).

231. Id. at 102.

232. Id. at 103 . 
questions about the first amendment with respect to cable.233 But the Court's deferential approach in DNC may commend itself here, especially since the Cable Act more specifically defines the bounds of regulation that Congress thought acceptable than did the statute interpreted in DNC. In that case the Court bowed to an administrative interpretation of the rather vague "public interest, convemience, and necessity" language governing broadcasting. ${ }^{234}$ Here, Congress specifically dictated the permissible limits of city regulation in several interrelated areas.

That the grant of exclusive licensing and the sclieme for access emanate directly from Congress, and not one of its agencies, strengthens the case for judicial deference. This distimction between congressional and agency judgment may be reflected in the Court's past unease at deferring to FCC judgments regarding cable absent a congressional blueprint. In the Midwest Video cases, ${ }^{235}$ the Court urged Congress eitler to address cable program rules or to provide specific authority to the FCC to do so. In the Cable Act, instead of giving the FCC general jurisdiction to de-

233. Quincy Cable TV, Inc. v. FCC, 768 F.2d 1434, 1449 (D.C. Cir. 1985); Omega Satellite Prods. Co. v. City of Indianapolis, 694 F.2d 119, 127 (7th Cir. 1982); Home Box Office, Inc. v. FCC, 567 F.2d 9, 45 n.80 (D.C. Cir.) (per curiam), cert. denied, 434 U.S. 829 (1977).

234. In United States v. Midwest Video Corp., 406 U.S. 649 (1972), the Court upheld a shortlived FCC requirement that a cable system carrying broadcast signals be required to originate programming itself. The crucial fifth vote was supplied by Chief Justice Burger, who noted:

Candor requires acknowledgment, for me at least, that the Commission's position strains the outer limits of even the open-ended and pervasive jurisdiction that has evolved by decisions of the Commission and the courts. The almost explosive development of CATV suggests the need of a comprehensive re-exammation of the statutory scheme as it relates to this new development, so that the basic policies are considered by Congress and not left entirely to the Commission and the courts.

Id. at 676 (Burger, C.J., concurring). The dissenters saw the same issue, but from the opposite vantage point:

[T]o entrust the Commission with the power to force some, a few, or all CATV operators into the broadcast business is to give it a forbidding authority. Congress may decide to do so. But the step is a legislative measure so extreme that we should not find it interstitially authorized in the vague language of the Act.

Id. at 681 (Douglas, J., dissenting) (emphasis added). In commenting on this case, Lee Bollinger, $\mathrm{J}_{\mathrm{r}}$, argued that limited access authorized by Congress could be sustained while smillar requirements enacted by the FCC under the 1934 Communications Act and applied to cable should not. Bollinger, Freedom of the Press and Public Access: Toward a Theory of Partial Regulation of the Mass Media, 75 Mich. L. REv. 1, 41-42 (1976).

235. FCC v. Midwest Video Corp., 440 U.S. 689 (1979), invalidated the FCC's four-channel access requirements on cable systenis of 20 or more channels. The Court concluded that Congress's views expressed in the 1934 Comnunications Act ran counter to the FCC's requirenent: "[W] are unable to ignore Congress' stern disapproval-evidenced in $\$ 3(\mathrm{~h})$-of negation of the editorial discretion otherwise enjoyed by broadeasters and cable operators alike." Id. at 708 . The Court concluded that "authority to compel cable operators to provide common carriage of public-originated transmissions must come specifically from Congress." Id. at 709. In an accompanying footnote, the decision indicated that its determination of the question rested on statutory grounds, and that it declined to express a view that the access requirements violated the first amendment rights of cable operators, noting that the assertion of the constitutional issue did not determine its constrnction of the statute. Id. at 709 n.19. 
velop a framework for cable's regulation, Congress settled many of these issues itself. ${ }^{236}$ To generalize, then, the Court may be reluctant to second-guess the federal legislature, or its agency in balancing first amendment interests, and when Congress is the source of that balance, deference is more preferable. ${ }^{237}$ This deference may have no exact parallel in other regulatory areas that affect speech concerns. But the Court's willinguess to defer to a federal statute ${ }^{238}$ despite nonfrivolous speech objections is not new or isolated to broadcasting. ${ }^{239}$

236. In fact, the Court has been quite deferential to the $\mathrm{FCC}$, as the $D N C$ case suggests. In part, deference to the agency may be due to its expertise. The FCC, not members of Congress (other than those few who through committee assignments have made commumications a specialty) is supposed to possess the expertise for regulating media. The scorecard of Supreme Court review of FCC broadcasting and cable-related deeisions since 1943, with the exception of the second Midwest Video appeal in 1979, has been consistent affirmance.

237. And the Court prefers the Commission to proceed upon specific authority rather than generalized powers. In City of New York v. FCC, 108 S. Ct. 1637 (1988), the Court approved the FCC's negative preemption of local technical standards governing cable, relying on powers granted by 47 U.S.C. $\$ 544$ (e) (Supp. III 1985). It declined to rule on the other, more generalized statutory bases asserted by the agency for its decision. $108 \mathrm{~S}$. Ct. at 1645 n.6.

238. The Court has not articulated a policy of deferring to the first amendment balance struck by state legislatures or administrative bodies in cases involving lawyer advertising or admission to the bar, regardless of whether the state decision at issue is upheld or reversed. Compare In re R.M.J., 455 U.S. 191 (1982) (invalidatimg Missouri rule regulatimg lawyer advertising) with Ohralik v. Ohio State Bar Ass'n, 436 U.S. 447 (1978) (upholding state regulation of in-person solicitation by lawyers) and Law Students Civil Rights Research Council, Inc. v. Wadmond, 401 U.S. 154 (1971) (upholding "character and general fitness" requirement for admission to N.Y. Bar).

239. In some areas of regulatory law, the speech question has been avoided altogether. For instance, ouly recently has the regulation of poitical speech in the context of securities trading been questioned under the first amendment. See Shiffrin, supra note 130, at 1214 n.9, 1230-31, 1265-70; see also Lowe v. SEC, 472 U.S. 181 (1985); cf. Carpenter v. United States, 108 S. Ct. 316 (1987). The Court has also deferred to Congress's line-drawing in ruling on claims against the portions of the Hatch Act, 5 U.S.C. $\S$ 7324(a)(2) (1982), that bar federal employees in the executive branch from taking "an active part in political management or in political campaigns." See Civil Serv. Comm'n v. National Ass'n of Letter Carriers, 413 U.S. 548, 556, 567 (1973) (upholding Congress's linedrawing over protected speech in political life); United Public Workers v. Mitchell, 330 U.S. 295, 299 (1947) (same). Consider, also, the way in which the Court looks to Congress's judgments in reviewing picketing cases under the Taft-Hartley Act, 29 U.S.C. $\$ 158(b)(4)$ (1982). It has construed the statute in a way that sustains the exercise of speech through picketing, despite the judgment of the National Labor Relations Board, Congress's supposedly expert agency on such matters, that the statute intended the contrary. See Edward J. DeBartolo Corp. v. Florida Gulf Coast Bldg. \& Constr. Trades Council, 108 S. Ct. 1392 (1988); NLRB v. Drivers, Chauffeurs, Helpers, Local Union 639, 362 U.S. 274, 284 (1960); cf. NLRB v. Fruit \& Vegetable Packers \& Warehousemen, Local 760, 377 U.S. 58, 63 (1964). Although the Court has not addressed the constitutionality of the Newspaper Preservation Act, 15 U.S.C. $\$ \S 1801-1804$ (1982), Ninth Circuit review in Committee for An Independent P-I v. Hearst Corp., 704 F.2d 467 (9th Cir.), cert. denied, 464 U.S. 892 (1983), involved considerations of deference to Congress. The Act permits competing but failing newspapers to enter into joint operating and distribution arrangements that otherwise would violate the antitrust laws. 15 U.S.C. $\S 1801$. Citizens challenged the antitrust exemption on the ground that allowing combinations between larger papers violated first amendment rights of smaller newspapers in the markets where combinations occurred. $704 \mathrm{~F} .2 \mathrm{~d}$ at 482 . The court classified the regulation as economic and not affecting the content of the smaller papers' speech, even though the court acknowledged that the 
While the foregoing certainly does not deınonstrate that courts must defer to Congress's every arrangeinent respecting cable, there is a good argument for deference to its judgment about exclusive franchising. First, it is part of a coinprehensive statute that includes access for excluded speakers as a central element. ${ }^{240}$ Isolating and overturning a single provision of the Act, such as exclusive hicensing, inay unrealistically elevate speech interests inhering there that are balanced out elsewhere in the statute. ${ }^{241}$ Second, franchising is a practice that under the terms of the Act cannot be based on the selection of particular program services. Exclusive franchising thus differs from content-based regulations, deference to which would repudiate the judiciary's primary role im protecting individual rights.

Third, despite the fact that cable television is over forty years old, the regulatory structure created by the Act is relatively new, and the wisdoin vel non of exclusive franchising-quite apart froin its impact on speech-is still revealing itself. Exclusive hicensing may not be a city's wisest course, particularly if the price of service is its dominant concern. The Act eliminated local rate regulation for most cable systems, ${ }^{242}$ and competitive franchises-or the threat of thein-might be viewed as a new tool in city franchising policy. The statute is, after all, permissive, not inandatory, as to exclusive franchises. The Court has, over the years,

exemption "may affect the number of 'readers' a newspaper has." 704 F.2d at 483 (emphasis in original). But since both the antitrust laws and the exemptions provided were discretionary with Congress, the law was sustained. Id. The appeals court's classification of the statute as "economic" notwithstanding, the case suggests that the Newspaper Preservation Act's antitrust exemption, with its effect on the press, is within Congress's discretionary power to grant.

240. See H.R. REP. No. 934, supra note 81, at 31, reprinted in 1984 U.S. CODE CONG. \& ADM1N. NEwS at 4668.

The committee [sic] is aware that access provisions have been challenged in the court as inconsistend with the First Amendment rights of the cable operator. The Committee believes, nonetheless, that the access provisions contained in this legislation are consistent with and further the goals of the First Amendment. The provision establish [sic] a form of content-neutral structural regulation which will foster the availability of a "diverS)ty of viewpoints" to the lisdening audience.

Id.

241. The Court in Buckley v. Valeo, 424 U.S. 1 (1975), undid the package of limitations worked out in the 1971 Federal Election Campaign Act, voiding the limits on expenditures but upholding the limits on contributions. The decision may have been wrong in its unrealistic overemphasis on expenditure speech rights over contribution rights and a campaign funding loophole never intended by Congress and now seemingly impossible to close. $C f$. id. at 259 (White, J., concurring in part and dissenting in part); see also FEC v. National Conservative Political Action Comm., 470 U.S. 480 (1985); Lowenstein, Campaign Spending and Ballot Propositions: Recent Experience, Public Choice Theory and the First Amendment, 29 UCLA L. REv. 505 (1982). Buckley could be distinguished here in that the balance drawn in the Cable Act is between different groups of speakers: some protect operators and access seekers; some restrict them. In Buckley, there was no similar balancing of first amendment interests. Rather, the balance concerned the interest in regulating campaign expenditures against the individual's right to exercise rights of expression by spending money.

242. 47 U.S.C. $§ 543(a)$ (Supp. III 1985). 
asked Congress to address the regulation of cable television. Given the legislature's willingness finally to do so in a comprehensive statute that includes trade-offs for both cities and systems, there is something to be said for developing experience under the statute before declaring a portion unconstitutional. ${ }^{243}$

Deference is not abdication, of course, and cities and established players in the cable industry cannot compromise away the rights of expression that a second cable operator might separately advance. However, the legislative history evidences a more than superficial appreciation of the first amendinent interests involved in cable. And the rights of nonoperators, such as they are, seein adequately represented in the statute's access provisions.

\section{CONCLUSION}

First amendment questions are usually settled by a balancing process that calls for judgments in areas where a court's intuition, though seldom made explicit, figures prominently. Intuition as to cable television and the freedom of expression is hard to come by. With cable, judginents must account for a inulti-dimensional inedium: cable's clann to first amendment protection depends on liow one characterizes the activity souglit be regulated. Move away from content-based regulation, as exclusive franchising and access regulations generally do, and the difficulties of the analysis are exacerbated by the essentially ad hoc, unpredictable status of the balancing exercise.

Generalized analogies do not offer much help. Analogizing cable to a newspaper overstates the editorial nature of cable enterprises as they actually have developed. Analogizing cable to a common carrier or broadcaster, with their more regulated regimes, ignores the considerable editorial activity in which cable operators engage. And it sells short what cable might accomplish as a medium of communication, given the encouragement of first ainendinent status.

The 1984 Cable Act differentiates among the different functions of an operator as it addresses competing first amendinent aspects of cable. The Act's permissive exclusive ticensing arrangement accurately reflects the lower level of expressive activity, from both the speaker's and audience's viewpoint, at stake at the franchise stage and so does not require a higl degree of scrutiny on review. The stakes of this permissive provi-

243. Buckley may represent a case in which the Court would have benefitted from seeing how the statute operated before developing a novel theory of expenditures and contributions as speech. See also Wright, Politics and the Constitution: Is Money Speech?, 85 YALE L.J. 1001 (1976). Perhaps the Court's decision to defer any decision in Preferred refiects a wait-and-see attitude. 
sion appear to be low, especially given the statute's access opportunities for excluded speakers. Those access provisions, in addition to addressing the rights of expression of excluded parties, avoid the shortcomings of like-ninded newspaper schenies and take advantage of cable's longpromised broadband capability.

Balancing the first amendnient concerns posed by exclusive franchising and access against a city's interest in using its police powers to provide easements and exercise eminent domain as it sees fit should lead to sustaining the Act's regulations. To the extent the question is a closer one, it is useful to take account of the limited experience so far under the legislation and the linkage of access and exclusive hicensing under the act. Doing so suggests that the Act presents a reasonable case for judicial deference to Congress's plan. 